\title{
Collapse, reorganization, and regime identity: breaking down past management paradigms in a forest-grassland ecotone
}

\author{
Victoria M. Donovan $^{1}, \underline{\text { Caleb P. Roberts }}^{1,2}, \underline{\text { Carissa L. Wonkka }}^{3}, \underline{\text { Daniel R. Uden }}^{1,2,4}$, David G. Angeler $^{5}, \underline{\text { Craig R. Allen }}^{2,4}, \underline{\text { David A. }}^{1}$
} $\underline{\text { Wedin }}^{2}$, Rhae A. Drijber ${ }^{1}$ and Dirac Twidwell ${ }^{1}$

\begin{abstract}
The identity of an ecological regime is central to modern resilience theory and our understanding of how systems collapse and reorganize following disturbance. However, resilience-based models used in ecosystem management have been criticized for their failure to integrate disturbance outcomes into regime identity. Assessments are needed to understand how well these classifications represent ecosystem responses that occur over management relevant time scales. We tracked post-wildfire forest and grassland dynamics 27 years after wildfire in eastern ponderosa pine savanna. We tested for differences between the assigned identity of a site (forest or grassland) versus classifications based on the site's disturbance history (burned/unburned and fire severity). Under current ecosystem models used to manage these forest-grassland ecotones, forests that experience high severity fire are expected to resemble an unburned grassland following fire, while forests and grasslands that experience low severity fire are expected to resemble unburned forests and grasslands, respectively. Twenty-seven years after wildfire, burned forests and grasslands displayed a high degree of departure from their expected regime identity. Plant and bird communities deviated significantly on sites that experienced low severity fire from undisturbed sites classified under the same ecological regime (grassland or forest). Forest sites that experienced high severity fire were the most unique of all disturbance history classes. Our results demonstrate that structures and communities predicted under resiliencebased models used for eastern ponderosa pine management do not emerge over management relevant time scales following disturbance. Over $20 \%$ of variation in ecological structures and communities was explained by a single, 27-year-old disturbance. Integrating disturbance legacies will help improve applied models of ecosystem dynamics.
\end{abstract}

Key Words: Alternative state, Collapse; Ecological memory, Ecological legacy; Ecotone; Regime identity, Reorganization, Resilience, State-and-transition model

\section{INTRODUCTION}

Rapid global change is expected to increase rates of ecosystem collapse across the globe, leading to abrupt and persistent shifts in ecosystem structure and function (Rocha et al. 2015). These dynamics are encompassed in modern resilience theory, bringing it to the forefront of global change policy. Ecological resilience theory was shaped by Holling (1973), where he proposed that a single system could exist in multiple alternative ecological regimes, each composed of their own unique structures, functions, and feedbacks that make up its regime identity. While systems can adapt and change over time, when a system under stress passes a critical threshold, it can collapse and reorganize into an alternate ecological regime (Scheffer et al. 2001, Cumming and Peterson 2017). The amount of change a system can absorb before transitioning to an alternate ecological regime is known as a system's resilience, and it is this emergent property of ecosystems that can be most useful for predicting and altering the probability of change (Holling 1973, Angeler and Allen 2016, Allen et al. 2019).

Concepts of resilience theory have been increasingly integrated into ecosystem management. Increasing evidence of sustained and sometimes irreversible losses of ecosystem services (Scheffer et al. 2001, Folke et al. 2004) has spurred numerous resiliencebased management frameworks that focus on preventing ecological regime shifts (i.e., The Nature Conservancy's Marine
Resilience Program; USDA Natural Resource Conservation Service's Ecological Site Descriptions). For instance, state-andtransition models (STMs) of community dynamics were developed following Holling's (1973) seminal paper as a conceptual framework for resilience-based management after substantial empirical evidence highlighted numerous cases where the assumptions of retrogression succession models did not hold (Westoby et al. 1989). State-and-transition models are being integrated into management and restoration frameworks across multiple continents (Grant 2006, Wong et al. 2010, Bestelmeyer et al. 2017).

Applied conceptual models of ecosystem dynamics are meant to represent critical ranges of complexity in systems that occur over management relevant time scales. Aspects of resilience theory that have been integrated into state-and-transition models propose that when an ecological regime experiences disturbance, it will 1) self-assemble into a similar set of structures and functions that existed prior to disturbance (Fig. 1b,c) or 2) reorganize into an alternative regime with a new set of stabilizing feedbacks that characterize the structures and functions of a new regime (Fig. 1a). Often, applied resilience-based conceptual models like stateand-transition models represent these dynamics by grouping locations into a regime identity based on dominant vegetation types (Fig. 1; Fig. A1.1; Twidwell et al. 2013, Bestelmeyer et al. 2017). While the objective of these frameworks is to better

${ }^{1}$ University of Nebraska-Lincoln, Department of Agronomy \& Horticulture, Lincoln, Nebraska, ${ }^{2}$ University of Nebraska-Lincoln, School of Natural Resources, Lincoln, Nebraska, ${ }^{3}$ United States Department of Agriculture-Agricultural Research Service, Northern Plains Agricultural Research Laboratory, MT, USA, ${ }^{4}$ University of Nebraska-Lincoln, Center for Resilience in Agricultural Working Landscapes, Lincoln, Nebraska, ${ }^{5}$ Swedish University of Agriculture Sciences, Department of Aquatic Sciences and Assessment, Uppsala, Sweden 
Fig. 1. Three depictions of predicted responses of alternative forest and grassland regimes that experience fire in eastern ponderosa pine. (A) A representation of a forest that burns at high severity, predicted to resemble an unburned grassland regime. (B) A representation of a forest that burns at low severity, predicted to resemble an unburned forest regime. (C) A representation of a burned grassland, predicted to resemble an unburned grassland regime. Photo credit: Victoria M. Donovan, Carissa L. Wonkka, and OpenSkyMedia (license CC by-nd 2.0).
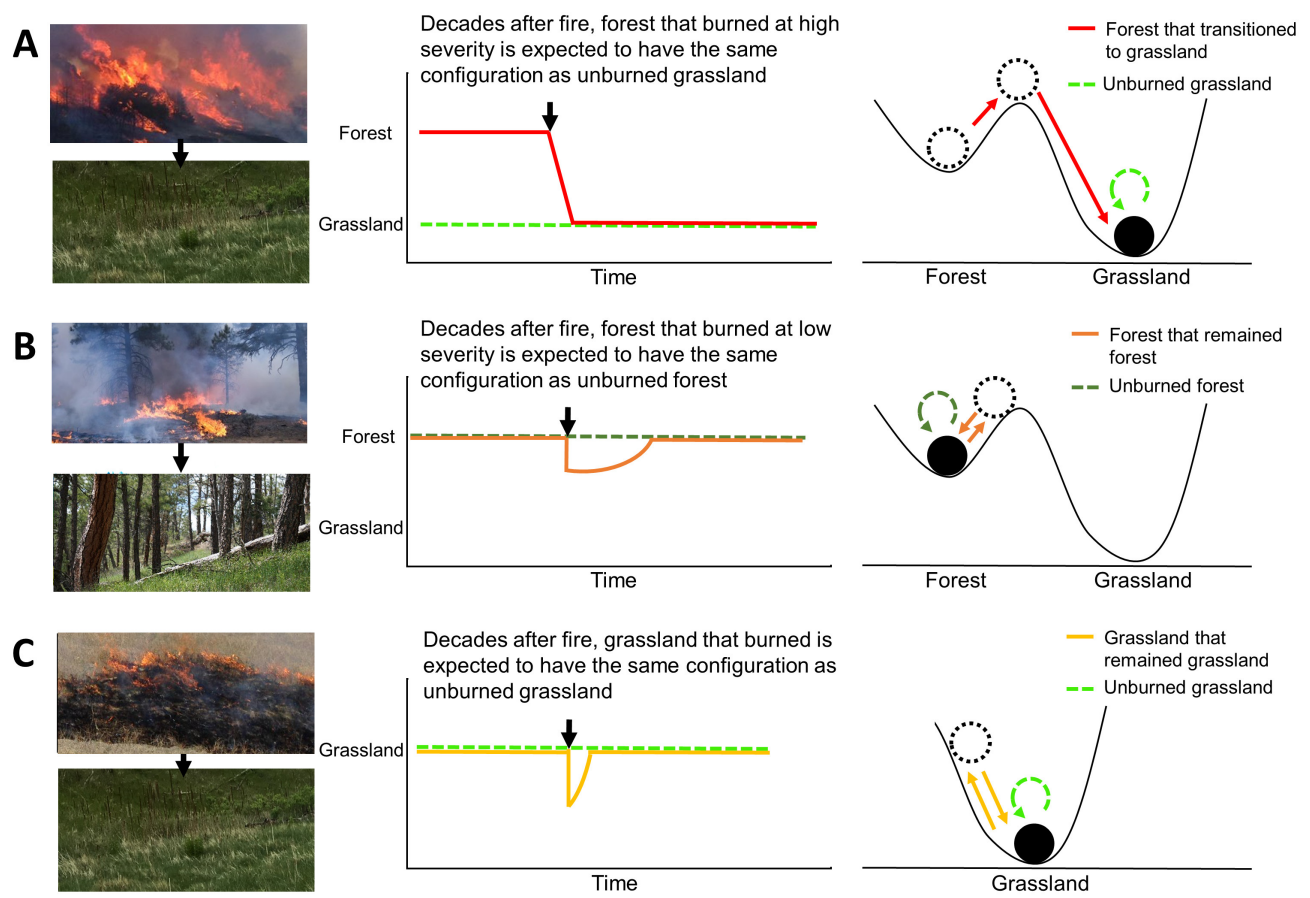

represent ecosystem function by incorporating complex behaviors like discontinuous vegetation transitions (Westoby et al. 1989), these classifications can often focus only on undisturbed ecosystem configurations. For instance, STMs used in a nationallevel land management framework in the United States have been criticized for focusing on returning systems to a desired historical vegetation reference community that occurred before perturbation (Twidwell et al. 2013). Grouping systems based on a simplified set of vegetation characteristics can guide management towards only one of the many ecosystem configurations within a given ecological regime important for maintaining resilience (Holling and Meffe 1996, Twidwell et al. 2013).

There is a wide body of research that supports the persistence of post-disturbance habitats that are important to biodiversity and system resilience (Turner et al. 1998, Swanson et al. 2010, Seidl et al. 2014, Johnstone et al. 2016, Roberts et al. 2019). The legacies of disturbances like fire can persist for several decades (Roberts et al. 2019). However, post-fire management activities like salvage logging, ground stabilization treatments, and tree planting are often implemented immediately following or a few years post-fire (USDA Forest Service 2007, Robichaud et al. 2010, Donovan et al. 2019). Similarly, ecosystem management plans often function on 5-10 year review cycles (Schneider et al. 2011, USDA Forest Service 2015). Thus, oversimplification of ecosystem models can lead to the elimination of disturbance legacies if they persist past these time frames. Assessing the ability of simplified regime identities to encompass disturbance-driven complexity that emerges over management relevant time scales can help determine whether the incorporation of disturbance legacies into ecosystem models will help managers better achieve ecosystem management objectives.

We assess the degree to which identification of regimes in resilience-based ecosystem models applied in eastern ponderosa pine forest capture forest and grassland dynamics following fire over management relevant time scales in the Pine Ridge region of western Nebraska. We sampled in a 27 -year-old mixed-severity wildfire perimeter that encompassed a mosaic of grassland and ponderosa pine forest that experienced minimal post-fire management, allowing for relatively unaltered reorganization following disturbance. STMs for this region predict alternative forest or grassland regimes (also known as alternative states), where shifts between regimes can be predicted by the presence or absence of high-intensity crown fire (Fig. A1.1). Three classical expectations based on the propositions generated by these models are that: 1) a forest that experiences high-intensity crown fire (equated with high severity fire) that exceeds system thresholds is expected to resemble unburned grasslands, 2) a forest that experiences low-intensity fire (equated with low severity fire) that does not exceed system thresholds is expected to resemble 
unburned forests, and 3) a grassland that experiences fire is expected to resemble unburned grasslands (Fig. A1.1; https://edit. jornada.nmsu.edu/). We contrast biological communities and ecosystem structural components across burned grasslands, unburned grasslands, forests that burned at high severity, forests that burn at low severity, and unburned forests using fire severity patterns from a 27-year-old fire perimeter to determine if there are differences between sites predicted to have the same ecosystem configuration in the majority of the region's STM models. Updates to some of these models have recently begun to include some fire legacies (e.g., Fig. A1.1; Fig. A1.2). Our study will highlight whether such updates add value to management frameworks and help determine if further detail is needed to encapsulate the full range of ecosystem dynamics generated by fire.

\section{METHODS}

\section{Study area}

The Pine Ridge consists of an elevated, rugged escarpment in northwest Nebraska, U.S. near the edge of Great Plains grasslands and western forests. The landscape mosaic consists of interspersed mixed-grass prairie and ponderosa pine (Pinus ponderosa) forest and savanna. The region falls within the 'Mixed Sandy and Silty Tableland and Badlands' Major Lands Resource Area designated by the USDA NRCS (2006). A number of mixedseverity fires since the mid-twentieth century have altered land cover and species composition (Roberts et al. 2019, Keele et al. 2019). In 1989, the mixed-severity Fort Robinson wildfire burned approximately 19,000 ha in and around Fort Robinson State Park, which lies at the northwest corner of Pine Ridge. Fire severity within the burn perimeter ranged from low to high, while some areas escaped fire completely (MTBS; https://www.mtbs.gov/). Little post-fire management (e.g., salvage logging) was conducted in Fort Robinson, but sporadic, low-intensity cattle grazing occurred before the fire and continued through the present study (2016).

Fire plays an integral role in the feedbacks that maintain grassland and forest regimes in eastern ponderosa pine. In grasslands, highly pyrogenic grasses promote low severity wildfire that kills woody plant seedlings, maintaining the resilience of the grassland regime (Woodcock 1992, Beckage and Ellingwood 2008). In ponderosa pine stands, low severity fires kill juvenile trees, maintaining an open stand structure more resilient to high-intensity wildfire than dense stand structures (Brown and Sieg 1999). Adult trees are resistant to low-intensity fires and help shade out grass and understory woody plant species, reducing surface fuels and decreasing the system's pyrogenicity (Scheffer et al. 2001, Odion et al. 2010). When high-intensity crown fires do ignite in ponderosa pine stands, high tree mortality can lead to a regime shift into an alternative grassland or shrubland regime (Allen et al. 2002, Noss et al. 2006, Odion et al. 2010). In the ponderosa pine of the Pine Ridge region, high-intensity crown fire is expected to lead to a regime shift from a forest to a grassland under the currently applied ecological framework (STMs; Fig. A1.1; A1.2).

STM framework used in the Pine Ridge refers to ecological regimes as alternative states, and regime shifts between these alternative states as 'state-transitions.' Within each alternative state, community phases can exist which represent transient dynamics among different species compositions that can occur within each state. Within this framework, we refer to all community phases within a given state as the management framework's representation of regime identity. No time frames are explicitly described within STM models, however, classification of transient dynamics versus state transitions is dependent on the length of time needed for recovery and management timelines (Bestelmeyer et al. 2017). In U.S. STMs, changes in vegetation are classified as state-transitions rather than a transient community phase when they take "several decades" to recover (Caudle 2013).

There are multiple ecological sites in the Pine Ridge region that can host alternative ponderosa pine and grasslands states (e.g., Ecological Sites R064XY040NE; GX064X01X036, R064XY032NE). The majority of these sites do not indicate any potential community phases that can exist from fire within either grassland or ponderosa pine states (https://edit.jornada.nmsu.edu/; Fig. A1.1). However, recent updates to the 'Shallow' ecological site (R064XY040NE) incorporate some fire legacy effects into forest regime's identity by adding a community phase that can exist when low-intensity fire occurs within a forest (Fig. A1.2). This update also added a new state that can occur following high-intensity fire that can eventually lead to a grassland state (Fig. A1.2).

\section{Data collection}

We used five transition classes, to test the three expectations proposed by STMs in this region: (1) unburned forest, (2) unburned grassland, (3) grassland that burned and is expected to resemble unburned grassland over management relevant time scales, (4) forest that burned at low intensity and is expected to resemble unburned forest over management relevant time scales, and (5) forest that burned at high intensity and is expected to resemble unburned grassland over management relevant time scales. Grasslands were defined as an area dominated by grasses that had no live trees present. Forests were areas that were dominated by ponderosa pine cover. We overlaid burn perimeters and fire severity classes designated by the Monitoring Trends in Burn Severity project (MTBS; https://www.mtbs.gov/) with historical Google Earth remote sensing imagery (https://www. google.com/earth/) to identify areas that fell into one of our five transition class categories. Forests that burned at low severity were equated with low-intensity fire. Forests that burned at high severity were equated with high-intensity crown fire because of associated near to complete stand mortality (Roberts et al. 2019). Sites that did not experience fire were selected in public lands along the outside of the fire perimeter to control for the effects of environmental variation in comparisons. We assumed unburned forests and grasslands had similar composition through time and did not experience any other disturbances. Sites were removed from our assessment when it was clear post-fire management had occurred or where we found records that management or re-burn had occurred.

We divided our assessments of each of these transition classes in to three comparisons: (1) live tree characteristics, (2) herbaceous community composition, and (3) other important ecosystem characteristics. Live tree characteristics are used to identify and distinguish among forests. Thus, we collected and contrasted live tree density, diameter at breast height $(\mathrm{DBH})$, and stand basal area among transition classes. Similarly, grasslands are largely 
characterized by herbaceous vegetation communities. Thus, we collected herbaceous species ground cover data and compared community composition across transition classes. Finally, we quantified ecological characteristics of grassland and forested systems that are not typically used in the classification of regime identity in STMs but have been shown to be ecologically significant. We measured coarse woody debris cover, snag density, and snag $\mathrm{DBH}$, all of which play unique roles in ecosystem function, such as creating habitat for wildlife and altering decay dynamics (Harmon et al. 1986, Mills et al. 2000, Kroll et al. 2014). We also measured understory woody plant community and structure, which play important roles in creating habitat and altering ecosystem dynamics (Allen et al. 2002, Kroll et al. 2014). Finally, to characterize wildlife responses among transition classes, we measured bird community composition. Although wildlife communities are not typically used to characterize ecological regimes, they can play an important role in structuring ecosystems and are often indicative of underlying changes in ecosystem dynamics that are not easily measured (Ostfeld and Keesing 2000, Goheen et al. 2018).

\section{Site selection}

Data were collected within the 1989 Fort Robinson mixed-severity wildfire perimeter that burned 19, 000 ha across a mixture of public and private lands (Fig. A1.3). We sampled forests and grasslands on public lands. Sampling across transition classes was divided among two years in two different sampling designs. Coarse woody debris (CWD), live tree and snag characteristics, understory woody plant community composition and structure, and bird community composition were sampled at 68 sites from May to August in 2016. We used a stratified-random sampling design to place 14 sites within each of the forest transition classes: unburned forest, forest that burned at low severity, and forest that burned at high severity. We placed 13 sites within each of the two grassland transition classes: unburned grassland and burned grassland. We restricted the distribution of our sampling sites to minimize time and maximize consistency for sampling bird communities. Geographically, we selected a 3,600 ha region with suitable road access within a portion of Fort Robinson State Park and adjoining Peterson Wildlife Management Area that contained adequate area for sampling each transition class within public lands. This area contained multiple low-use roads and trails that allowed for rapid access to sites within a short sampling window (see bird sampling description below).

Herbaceous community composition was sampled separately at 30 sites between June and August in 2015 within Fort Robinson State Park, which encompassed the majority of the fire perimeter (Fig. A1.3). A stratified-random sampling design was used to designate six sites within each transition class for herbaceous sampling.

\section{Live tree and snag characteristics}

We centered a 30 by $30 \mathrm{~m}$ plot on each sampling point. To calculate density, we counted and identified to species all trees and snags rooted and standing within each plot. We also measured diameter at breast height $(\mathrm{DBH})$ for all live trees and snags within plots that were $>1.4 \mathrm{~m}$ tall.

\section{Herbaceous plant community}

We established a 100m transect at each herbaceous sampling site. We sampled twenty $1 \mathrm{~m}^{2}$ quadrats along each transect. In each quadrat, we determined the cover of each vascular plant species $<1 \mathrm{~m}$ in height. We estimated cover for each species within quadrats using the following Daubenmire cover classes: $<1 \%$, $1-5 \%, \quad 5-25 \%, \quad 25-50 \%, \quad 51-75 \%, \quad 76-95 \%$, and $96-100 \%$ (Daubenmire 1959). The midpoint of the range for each cover class was assigned as the species cover (e.g., if a species fell within the cover class $25-50 \%$, we recorded its cover as $37.5 \%$ ). Species cover was averaged across quadrats to obtain a single value per transect before analysis $(n=30)$.

\section{Coarse woody debris}

Coarse woody debris (CWD) ground coverage was measured using a $30 \mathrm{~m}$ transect centered on each sampling point. For each site, we randomly chose the direction of the transect: north-south or east-west. We then used the line intercept method to record the total transect length overlapped by fallen woody debris $\geq 10 \mathrm{~cm}$ in diameter.

\section{Understory woody plant community}

We measured understory woody plant (saplings $<1.4 \mathrm{~m}$ [breast height] and shrubs) cover and structure at each site using five 5 $\mathrm{m}$ radius circular sampling plots. One plot was centered on the selected sampling point, while the remaining four were centered $15 \mathrm{~m}$ from the center of the sampling site in each of the four cardinal directions. Percent cover was estimated for each understory woody plant species within each plot and then averaged for each site. Understory woody plant structure was quantified by measuring the height of five randomly selected plants of each species within each of the five sampling plots, and then averaging plant height across plots to get an average measure for each species at each site.

\section{Bird community}

We used visual and aural point count surveys to quantify bird community composition at sampling sites. We conducted surveys between May 25th and June 8th, beginning 30 minutes prior to sunrise and ending 5 hours after sunrise. We did not conduct surveys if winds exceeded $20 \mathrm{~km} / \mathrm{h}$ or during precipitation events (Huff et al. 2000, Flanders et al. 2006). All bird species that were seen or heard during a 5 -minute period within $50 \mathrm{~m}$ of a point were recorded as present (Buckland et al. 2001). We revisited each point once within 5 days to increase the probability of detecting all present species (Sliwinski et al. 2016). Species records were pooled across visits as presence-absence values.

\section{Analysis}

We summarized patterns in live ponderosa tree density, DBH, and stand basal area at each sample site to characterize potential differences in stand structure across transition classes. Because ponderosa pine stands were primarily monocultures, with only two other species (Celtis occidentalis and Juniperus sp.) comprising only $0.6 \%$ of all of the trees recorded, we did not assess tree community patterns.

We used Redundancy Analysis (RDA; a form of constrained ordination) to assess variation in herbaceous community composition and ground cover across transition classes (our constraining variable), adjusting for rare species using a Chord transformation (Legendre and Gallagher 2001). An RDA with a Hellinger transformation was similarly used to ordinate z-score standardized CWD cover, snag density, mean snag DBH, bird community composition, and understory woody plant 
community composition and structure. Multiple-comparisons PERMANOVA was used to assess differences among transition classes for both ordination analyses. All statistical analyses were conducted in R statistical software (v. 3.4.0; 'vegan' package; Oksanen et al. 2016).

\section{RESULTS}

Expectation 1: A forest that experiences high severity fire will resemble an unburned grassland after 27 years

Three of 14 forest sites that experienced high severity fire had live ponderosa pine trees. Mean live ponderosa pine density across forest sites that burned at high severity was 14 trees/ha $\pm 9.77 \mathrm{SE}$ while mean basal area was $0.23 \mathrm{~m}^{2} / \mathrm{ha} \pm 0.22 \mathrm{SE}$ (Fig. 2). Average live ponderosa pine DBH across sites with live trees was $8.64 \mathrm{~cm}$ $\pm 3.68 \mathrm{SE}$. There were no live trees in unburned grassland sites (Fig. 2).

Fig. 2. Mean live ponderosa pine tree density (A), mean live ponderosa pine tree diameter at breast height (B), and live ponderosa pine basal area $(\mathrm{C})$ across unburned forest sites $(\mathrm{F})$, forest sites that burned at low severity and are expected to resemble unburned forest $(\mathrm{F}->\mathrm{F})$, forest sites that burned at high severity and are expected to resemble unburned grassland sites $(F->G)$, unburned grassland sites $(G)$, and grassland sites that burned and are expected to resemble unburned grassland (G->G).

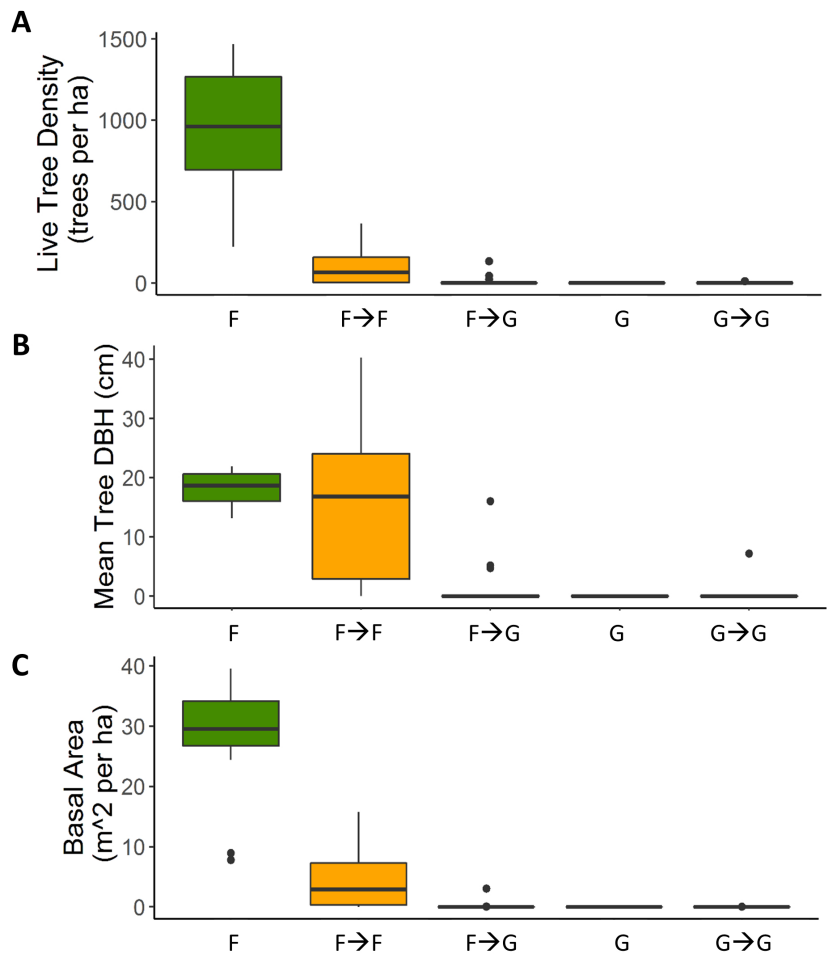

Herbaceous communities in forests that burned at high severity differed significantly from communities in unburned grasslands (Table 1). Herbaceous communities were largely differentiated by what was classified as grassland and forest before wildfire along Axis 1 (Fig. 3, 63\% of explained variation; Table A1.1,2), while
Axis 2 differentiated herbaceous communities based on the legacy of wildfire (Fig. 3, 23\% of explained variation; Table A1.1, 2). Forests that burned at high severity were differentiated from unburned grasslands along both Axis 1 and Axis 2.

Fig. 3. Redundancy Analysis (RDA) of herbaceous plant community and ground cover constrained by transition class (unburned forest sites [F], forest sites that burned at low severity and are expected to resemble unburned forest $[\mathrm{F}->\mathrm{F}]$, forest sites that burned at high severity and are expected to resemble unburned grassland sites $[\mathrm{F}->\mathrm{G}]$, unburned grassland sites $[\mathrm{G}]$, and grassland sites that burned and are expected to resemble unburned grassland $[\mathrm{G}->\mathrm{G}]$.) Points represent species score locations. Outer points have species labels. RDA1 differentiates between regimes, while RDA2 represents variation driven by long-term legacy effects following wildfire.

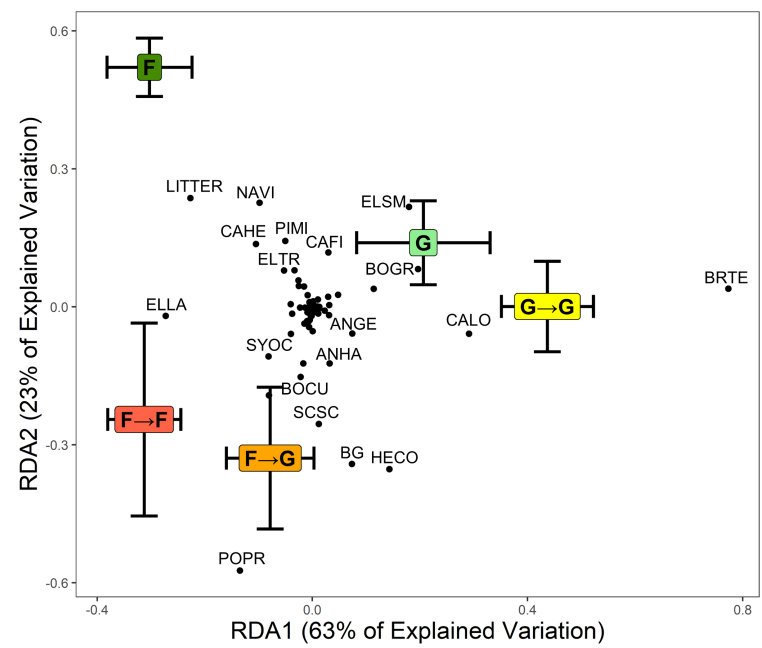

Among all sites that experienced fire, forests that burned at high severity had the greatest level of uniqueness in herbaceous communities from unburned forests and grasslands (Fig. 3). Almost double the number of herbaceous species were found at forest sites that burned at high severity (112 species) compared to unburned grassland (65 species). There were 60 herbaceous species found in forests that burned at high severity that were not present at any unburned grassland sites. Unburned grasslands hosted 16 species that were not found in forests that burned at high severity. Forests that burned at high severity also had 18 unique herbaceous species (species only recorded in that transition class), which was the highest of any transition class assessed (Table A1.5).

Forest sites that burned at high severity differed significantly from unburned grassland sites in other ecological characteristics as well (understory woody plant community, understory woody plant structure, CWD, snag characteristics, and bird community; Table 1). Again, Axis 1 largely differentiated between what was considered grassland and forest before wildfire (Fig. 4; 57\% of explained variation; Table A1.1, A1.2), which were most strongly driven by the presence of Ammodramus savannarum, along with the height of understory woody plant species Rhus trilobata and Toxicodendron radicans. Axis 2 largely represented the legacy of 
wildfire (Fig. 4; 21\% of explained variation; Table A1.1, A1.2). Patterns in Axis 2 were tied in part to the presence of the bird species Sturnella neglecta, Ammodramus savannarum, and Setophaga coronata auduboni, along with snag density (Fig. 4). Sturnella neglecta were strongly associated with burned communities, while Setophaga coronata auduboni, Ammodramus savannarum, and greater snag density were associated with unburned sites.

Fig. 4. Redundancy analysis (RDA) of bird and understory woody plant community, understory woody plant structure, snag characteristics, and coarse woody debris constrained by transition class (unburned forest sites [F], forest sites that burned at low severity and are expected to resemble unburned forest $[\mathrm{F}->\mathrm{F}]$, forest sites that burned at high severity and are expected to resemble unburned grassland sites [F-> G], unburned grassland sites [G], and grassland sites that burned and are expected to resemble unburned grassland $[\mathrm{G}->\mathrm{G}]$ ). Points represent species score locations. Outer points have species labels. RDA1 largely differentiates among regimes while RDA2 represents variation driven by long-term legacy effects following wildfire.

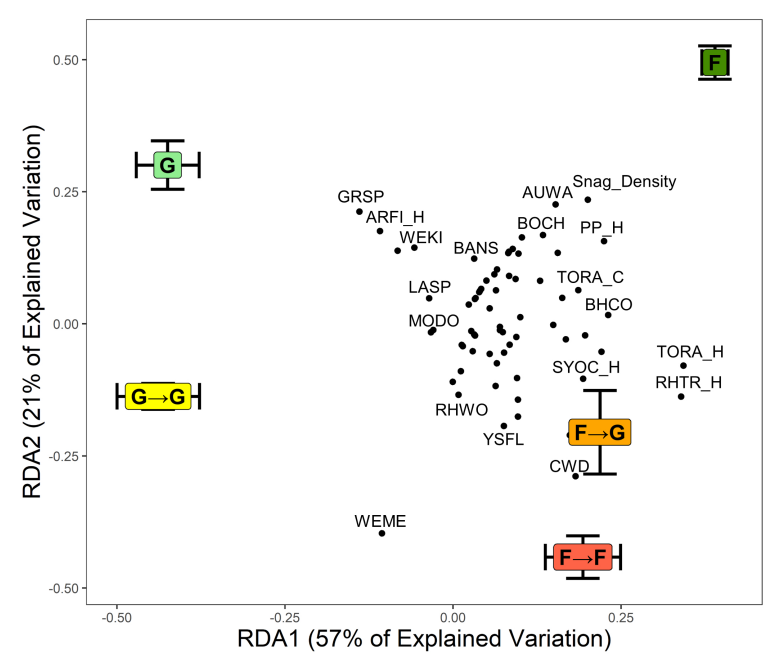

Forests that experienced high severity fire were more strongly associated with forest sites than grassland sites along Axis 1 (Fig. 4). Forest sites that burned at high severity had an average of $8.5 \% \pm 1.77$ SE CWD cover, and an average snag density of 6 snags/ha $\pm 2.54 \mathrm{SE}$. Grassland sites did not contain any CWD or snags. There was a greater diversity of bird and understory woody plant species in forests that burned at high severity compared to unburned grasslands. We recorded 14 species of birds in forests that burned at high severity, while there were only 8 bird species recorded in unburned grasslands. Similarly, there were 10 species of understory woody plants in forests that burned at high severity, and only 4 species of understory woody plants in unburned grasslands. There were 10 species of birds and 7 species of understory woody plants recorded in forests that burned at high severity that were not recorded in unburned grassland sites, while there were 4 species of birds and 1 species of understory woody plant that were found in unburned grasslands that were not found in forests that burned at high severity. Toxostoma rufum was the only species unique to forests that burned at high severity across all transition classes (Table A1.6).

\section{Expectation 2: A forest that experiences low severity fire will resemble an unburned forest after 27 years}

Live ponderosa pine density was $\sim 8$ times lower in forests that burned at low severity (115 trees/ha $\pm 32.61 \mathrm{SE})$ compared to unburned forest sites (931 trees/ha \pm 106.59 SE; Fig. 2), while mean basal area was almost 6 times lower $\left(4.80 \mathrm{~m}^{2} / \mathrm{ha} \pm 1.31 \mathrm{SE}\right.$ versus $28.58 \mathrm{~m}^{2} / \mathrm{ha} \pm 2.63 \mathrm{SE}$; Fig. 2). Average tree DBH across sites with live trees present was slightly greater in forests that burned at low severity $(22.47 \mathrm{~cm} \pm 2.63 \mathrm{SE})$ than in unburned forests $(18.17 \mathrm{~cm} \pm 0.79 \mathrm{SE}$; Fig. 2). Forests that burned at low severity had greater variation in DBH across sites $(125.88 \mathrm{~cm}$ $\pm 26.15 \mathrm{SE})$ compared to unburned forests $(81.31 \mathrm{~cm} \pm 13.83 \mathrm{SE})$.

Herbaceous plant communities in forests that burned at low severity did not significantly differ from unburned forests (Table 1). Unburned forests and forests that burned at low severity were very closely aligned along Axis 1 (which was associated with prefire forests versus grasslands), while they were strongly differentiated along Axis 2 (which was associated with the legacy of disturbance; Fig. 3). Species richness was higher in forests that burned at low severity, with a total of 88 herbaceous species in forests that burned at low severity, in comparison to 71 herbaceous species in unburned forests. There were 23 herbaceous species that were found in forests that burned at low severity that were not found in unburned forests. Similarly, there were 18 herbaceous species recorded in unburned forests that were not found in forests that burned at low severity. Eight herbaceous species were unique to forests that burned at low severity while unburned forests had 10 unique herbaceous species (Table A1.5).

Forests that burned at low severity differed significantly from unburned forests in other ecological characteristics (Table 1). Forests that burned at low severity were similar to unburned forests along Axis 1 but were strongly differentiated from unburned forests along Axis 2 (Fig. 4). Average CWD cover was similar in both unburned forests and forests that burned at low severity $(1.01 \% \pm 0.41 \mathrm{SE}$ versus $2.42 \% \pm 0.62 \mathrm{SE})$. Snag density was 5 times greater in unburned forests ( $110 \mathrm{snags} / \mathrm{ha} \pm 22.33 \mathrm{SE})$ compared to forests that burned at low severity (22.22 snags/ha $\pm 8.66 \mathrm{SE})$. Similarly, snags in sites that burned at low severity had a larger average DBH than unburned forests $(23.09 \mathrm{~cm} \pm 3.01$ $\mathrm{SE}$ versus $17.31 \mathrm{~cm} \pm 4.61 \mathrm{SE})$. There were 24 bird species and 9 understory woody plant species recorded in forests that burned in low severity, while there were 23 bird species and 15 understory woody plant species recorded in unburned forests. There were 11 bird species and 1 understory woody plant species recorded in forests that burned at low severity that were not recorded in unburned forests, while there were 10 bird species and 6 understory woody plant species that were recorded in unburned forests that were not recorded in forests that burned at low severity. Of these species, 3 bird species and 1 understory woody plant species were unique to forests that burned at low severity (Table A1.6). Unburned forests had 7 unique bird species and 5 unique understory woody plant species not recorded in any other transition class (Table A1.6). 
Table 1. Multiple PERMANOVA comparisons of forest stand structure, bird community, understory woody plant community, and herbaceous community data collected in 2015 and 2016 from sites within and surrounding the perimeter of the 1989 Fort Robinson wildfire, Nebraska, USA. Sites were categorized by transition class. The first column heading describes the comparison among transition classes, "Herbaceous Community" indicates PERMANOVA outputs comparing herbaceous community among transition classes, and "Additional Ecosystem Characteristics" indicates PERMANOVA outputs comparing forest stand structure, bird community, and understory woody plant community.

\begin{tabular}{|c|c|c|c|c|}
\hline \multirow[t]{2}{*}{ Severity Comparison } & \multicolumn{2}{|c|}{ Herbaceous Community } & \multicolumn{2}{|c|}{ Additional Ecosystem Characteristics } \\
\hline & F-value & Adjusted P-value & F-value & Adjusted P-value \\
\hline $\begin{array}{l}\text { Forest Unburned vs. } \\
\text { Forest } \rightarrow \text { Grassland }\end{array}$ & 2.82 & 0.01 & 11.61 & $<0.01$ \\
\hline $\begin{array}{l}\text { Forest Unburned vs. } \\
\text { Forest } \rightarrow \text { Forest }\end{array}$ & 1.30 & 0.28 & 15.63 & $<0.01$ \\
\hline $\begin{array}{l}\text { Forest Unburned vs. } \\
\text { Grassland Unburned }\end{array}$ & 2.78 & 0.01 & 20.35 & $<0.01$ \\
\hline $\begin{array}{l}\text { Forest Unburned vs. } \\
\text { Grassland } \rightarrow \text { Grassland }\end{array}$ & 4.54 & 0.01 & 20.48 & $<0.01$ \\
\hline $\begin{array}{l}\text { Forest } \rightarrow \text { Grassland vs. } \\
\text { Forest } \rightarrow \text { Forest }\end{array}$ & 1.16 & 0.28 & 2.41 & 0.02 \\
\hline $\begin{array}{l}\text { Forest } \rightarrow \text { Grassland vs. } \\
\text { Grassland Unburned }\end{array}$ & 1.97 & 0.08 & 5.96 & $<0.01$ \\
\hline $\begin{array}{l}\text { Forest } \rightarrow \text { Grassland vs. } \\
\text { Grassland } \rightarrow \text { Grassland }\end{array}$ & 1.89 & 0.08 & 5.81 & $<0.01$ \\
\hline $\begin{array}{l}\text { Forest } \rightarrow \text { Forest vs. } \\
\text { Grassland Unburned }\end{array}$ & 1.93 & 0.10 & 5.62 & $<0.01$ \\
\hline $\begin{array}{l}\text { Forest } \rightarrow \text { Forest vs. } \\
\text { Grassland } \rightarrow \text { Grassland }\end{array}$ & 3.00 & 0.04 & 6.07 & $<0.01$ \\
\hline $\begin{array}{l}\text { Grassland Unburned vs. } \\
\text { Grassland } \rightarrow \text { Grassland }\end{array}$ & 0.86 & 0.54 & 2.60 & 0.02 \\
\hline
\end{tabular}

Expectation 3: A grassland that experiences fire will resemble an unburned grassland

There was one live ponderosa pine tree recorded in burned grasslands (Fig. 2), along with a single live Celtis occidentalis. No live tree species were recorded in unburned grasslands.

Grasslands that burned hosted a higher herbaceous species richness than unburned grasslands. There were 77 herbaceous species recorded in burned grasslands in comparison to 65 species in unburned grasslands. However, herbaceous communities did not differ significantly between burned and unburned grasslands (Table 1). Burned and unburned grasslands were more strongly differentiated along Axis 1, while they were more closely aligned on Axis 2 (Fig. 3). Twenty-seven herbaceous species recorded in burned grasslands were not found in unburned grasslands. Of these, 8 herbaceous species were unique to burned grasslands (Table A1.5). There were 21 herbaceous species found in unburned grassland that were not recorded in burned grasslands, with 7 of these being unique to unburned grasslands (Table A1.5).

Burned and unburned grasslands differed significantly in other ecological characteristics (Table 1). Burned and unburned grasslands were strongly aligned along Axis 1 (Fig. 4). On Axis 2, burned grasslands were differentiated from unburned grasslands and instead were more aligned with forests that burned at low severity. This pattern is driven by the presence of the bird species Ammodramus savannarum, which was unique to unburned grasslands, and Sturnella neglecta, which was associated with burned sites. There were almost double the number of bird species recorded in burned grasslands compared to unburned grasslands (14 versus 8 , respectively), while there were 4 understory woody plant species recorded in unburned grasslands and 3 understory woody plant species recorded in burned grasslands. Unburned grasslands only had 3 bird species and 1 understory woody plant species in common with burned grasslands, while there were 11 bird species and 2 understory woody plant species recorded in burned grasslands but not in unburned grasslands. Unburned grasslands and burned grasslands each had 1 unique bird species that was not recorded in any other transition class: Ammodramus savannarum and Falco mexicanus, respectively (Table A1.6). There were no unique species of understory woody plants recorded in burned grasslands, and only a single unique species, Artemisia filifolia, recorded in unburned grasslands (Table A1.6). There was a single Juniperus sp. snag as well as a piece of CWD recorded at one burned grassland site.

\section{DISCUSSION}

Twenty-seven years after disturbance from wildfire, forest and grasslands displayed a high degree of departure from their expected regime identity based on propositions generated from applied conceptual models for this system. Forest expected to transition into a grassland following high severity fire hosted significantly different community compositions and structures than unburned grasslands. Forests that burned at low severity and are generally grouped as having the same ecological structures as unburned forests had distinct forest structural characteristics and communities. Burned grasslands expected to resemble unburned grasslands based on conceptual model propositions of regime identity hosted distinct community compositions. Similar to observations made in multiple other systems (Whittle et al. 1997, Gibson et al. 2016, Angeler et al. 2017), patterns in disturbance history have profoundly altered community composition. Twenty-seven years after fire, these findings are not in line with 
the propositions of the majority of STMs for this region which propose that reorganization following disturbance will return a system to a pre-disturbance configuration over management relevant time scales. Only a portion of Axis 1 and none of Axis 2 from our ordination analyses were represented by the regime identities reflecting dominant vegetation type. In our system, over $20 \%$ of variation in ecological structures and communities was explained by a single, 27-year-old disturbance event. Although sampling in the future may reveal different patterns, showing either recovery trends or stabilization of the patterns we identified here, our results demonstrate that these trends are not observed over management relevant time scales following disturbance. These finding echo numerous studies from other systems which highlight the importance of disturbance legacies (Swanson et al. 2010, Perry et al. 2011, Seidl et al. 2014, Johnstone et al. 2016) and support updates to applied ecological frameworks that incorporate disturbance legacies (Fig. A1.1; Fig. A2.2). Disturbance legacies are a defining factor of regime identity (Turner et al. 1998, Johnstone et al. 2016) that should be better incorporated into our applied models of ecosystem dynamics.

Disturbance patterns can dictate a system's ecological memory and define ecosystem resilience (Berkes et al. 2003, Johnstone et al. 2016). The memory of past ecosystem regimes is transmitted as legacies both through species adaptations and biotic and abiotic structures that alter system reorganization (Johnstone et al. 2016). In our study, sites that were expected to transition from forest to grasslands based on STM model propositions had herbaceous communities that were more similar to sites that would be classified under the regime identity of forest rather than grassland. They also hosted much higher herbaceous, understory woody plant, and avian species diversity. Structural legacies that are not typically included in regime identity classifications in STMs, such as snags and coarse woody debris, also differentiated these sites from grasslands. Variations in system reorganization created by factors like disturbance intensity can alter the ecological legacies that persist, creating variations in ecosystem structure and composition (Porensky et al. 2016, Johnstone et al. 2016). We show that legacies of disturbance can persist for decades in eastern ponderosa pine: even 27 years after wildfire, the ecological structure and composition of forests and grasslands that burned at low severity differed from forests that experienced high severity fire and those undisturbed by fire.

Disturbance allows a system to reorganize to encompass novel combinations of structures and functions (Berkes et al. 2003). We capture a number of system intricacies that are not used to assign the identity of an ecological regime in state-and-transition models for this region, such as bird community, snags, and coarse woody debris. This complexity creates distinctive structures and communities among the transition classes we assessed in eastern ponderosa pine. Grasshopper Sparrows (Ammodramus savannarum), described as a grassland generalist (Hovick et al. 2011), were strongly associated with undisturbed grasslands, while Western Meadowlarks (Sturnella neglecta), a grassland bird species, were highly associated with disturbed sites, regardless of whether they were 'forest' or 'grassland'. Species typically restricted to disturbed areas are rarely accounted for when describing the identity of a regime. Certain species of animals, plants, lichens, and fungi can be largely restricted to severely burned areas (Ahlgren and Ahlgren 1960, Heinselman 1981, Pilz et al. 2004, Hutto et al. 2015). The purpose of resilience-based ecosystem classification procedures like state-and-transition models is to more closely reflect complex dynamics in nature (Twidwell et al. 2013). Our simple study captured the complexity that emerges and persists following disturbance in eastern ponderosa pine that should be accounted for in STMs for this system. Integrating disturbance legacies into ecological regime models and definitions of regime identities will allow for a more realistic portrayal of system dynamics.

The integrity of ecosystem processes and biodiversity can be severely compromised when land management activities are too narrowly focused (Holling and Meffe 1996, Lindenmayer et al. 2008, Hiers et al. 2016). Restricting ecosystem identity to predisturbance ecosystem configurations can lead to management activities that eliminate ecological complexity and diversity create by the outcomes of disturbance that are integral to resilience. Clearing residual woody debris and snags is undertaken to reduce fire risk or increase grazing potential in forest sites that burned at high severity and are predicted to transition to grasslands (Fraver et al. 2011). Snag and CWD removal can lead to decreased abundance and diversity of cavity- and open-nesting birds as well as decreased biomass of invertebrates (Hutto and Gallo 2006, Riffell et al. 2011, Donovan et al. 2019). Post-fire seeding of grasses can be used to decrease soil erosion and promote grassland regeneration following severe fire (Noss et al. 2006). However, such practices have been shown to hinder tree regeneration and the recovery of native plant communities (Beyers 2004). Postsalvage logging is used to recuperate economic losses caused by fire drastically altering post-fire habitats, while reforestation is used to promote rapid forest regeneration following forest fire to more quickly reach pre-disturbance forest densities (DellaSala et al. 2006, Castro et al. 2011). These actions can promote the erosion of emergent novel patterns and behaviors, along with the ecological legacy of the previous system regime (Lindenmayer et al. 2004, Noss et al. 2006). Updating applied ecosystem management models to incorporate the ecological significance of these legacies will be integral to their consideration during management planning.

Regime identity needs to go beyond a simplified set of predisturbance vegetation characteristics in our applied models of ecosystem dynamics. Post-disturbance habitats attract and sustain high levels of biodiversity and can play integral roles in ecosystem process, yet they have been overlooked as transitional phases that lead towards the resumption of pre-disturbance ecosystem configurations resulting in management activities that eliminate or reduce post-disturbance biodiversity (Swanson et al. 2010). We demonstrate that the application of regime identification schemes used to manage eastern ponderosa pine communities underestimates the role of system collapse and reorganization in shaping system dynamics. Many current applications of alternative regime dynamics used in STMs do not adequately capture the importance of complexity, legacy, and novel patterns and processes in ecosystems (Twidwell et al. 2013). Our results support updating models to incorporate disturbance legacies into regime identities for both ponderosa pine forests and grasslands. Continuing to develop and enhance models of ecosystem dynamics in management that emphasize the importance of collapse and reorganization will be imperative. Current models could draw from alternative models that have 
been developed in ecology to better measure resilience (Baho et al. 2017). For instance, the adaptive cycle models community dynamics as a function of re-organization, highlighting its importance for determining the trajectory of a system (Holling 1986, Gunderson and Holling 2002, Allen et al. 2014, Sundstrom and Allen 2019).

Ecologists and managers increasingly recognize that the complexity of ecosystems needs to be accounted for to manage effectively (Angeler et al. 2016). Incorporating greater ranges of complexity important to ecosystem resilience into ecosystem management becomes increasingly plausible as technology continues to advance at an unprecedented rate allowing for more detailed characterizations of ecosystems at a greater range of spatial and temporal scales (e.g., Jones et al. 2018). Our study indicates breaking down past paradigms of disturbance legacies will better capture system dynamics in applied ecosystem models. Ecologists and resource managers who do so will be more effective at preventing undesired regime shifts and maintaining ecological diversity.

Responses to this article can be read online at: https://www.ecologyandsociety.org/issues/responses. php/12340

\section{Acknowledgments:}

This work was supported by the USDA NIFA, McIntire Stennis project 1008861, the Department of Defense Strategic Environmental Research Development Program W912HQ-15C-0018, and the University of Nebraska-Lincoln's Department of Agronomy \& Horticulture. The Nebraska Cooperative Fish and Wildlife Research Unit is jointly supported by Hatch Act funds through a cooperative agreement between the U.S. Geological Survey, the Nebraska Game and Parks Commission, the University of Nebraska Agricultural Research Division, Lincoln, Nebraska the United States Fish and Wildlife Service and the Wildlife Management Institute. We extend special thanks to the Nebraska Game and Parks Commission, especially to Gerry Steinauer for input on experimental design and to Mike Morava at Fort Robinson State Park and Greg Schenbeck at Peterson Wildlife Management Area, for allowing us to conduct this research on their lands. Finally, we thank Grace Kostel, Sarah Nodskov, and Emma Keele for assistance in data collection.

\section{Data Availability:}

The doi associated with the data is: https://doi.org/10.5061/dryad. mw6m905wm

\section{LITERATURE CITED}

Ahlgren, I., and C. E. Ahlgren. 1960. Ecological effects of forest fires. The Botanical Review 26(4):483-533. https://doi. org/10.1007/BF02940573

Allen, C. D., M. Savage, D. A. Falk, K. F. Suckling, T. W. Swetnam, T. Schulke, P. B. Stacey, P. Morgan, M. Hoffman, and J. T. Klingel. 2002. Ecological restoration of southwestern ponderosa pine ecosystems: a broad perspective. Ecological Applications 12(5):1418-1433. https://doi.org/10.1890/1051-0761 (2002)012[1418:EROSPP]2.0.CO;2

Allen, C. R., D. G. Angeler, B. C. Chaffin, D. Twidwell, and A. Garmestani. 2019. Resilience reconciled. Nature Sustainability 2 (10):898-900. https://doi.org/10.1038/s41893-019-0401-4

Allen, C. R., D. G. Angeler, A. S. Garmestani, L. H. Gunderson, and C. S. Holling. 2014. Panarchy: Theory and Application. Ecosystems 17(4):578-589. https://doi.org/10.1007/s10021-013-9744-2

Angeler, D. G., and C. R. Allen. 2016. Quantifying resilience. Journal of Applied Ecology 53(3):617-624. https://doi. org/10.1111/1365-2664.12649

Angeler, D. G., C. R. Allen, C. Barichievy, T. Eason, A. S. Garmestani, N. A. J. Graham, D. Granholm, L. H. Gunderson, M. Knutson, K. L. Nash, R. J. Nelson, M. Nyström, T. L. Spanbauer, C. A. Stow, and S. M. Sundstrom. 2016. Management applications of discontinuity theory. Journal of Applied Ecology 53(3):688-698. https://doi.org/10.1111/1365-2664.12494

Angeler, D., S. Drakare, R. Johnson, S. Köhler, and T. Vrede. 2017. Managing ecosystems without prior knowledge: pathological outcomes of lake liming. Ecology and Society 22(4): 44. https://doi.org/10.5751/ES-09794-220444

Baho, D., C. Allen, A. Garmestani, H. Fried-Petersen, S. Renes, L. Gunderson, and D. Angeler. 2017. A quantitative framework for assessing ecological resilience. Ecology and Society 22(3)17. https://doi.org/10.5751/ES-09427-220317

Beckage, B., and C. Ellingwood. 2008. Fire feedbacks with vegetation and alternative stable states. Complex Systems 18 (1):159. https://doi.org/10.25088/ComplexSystems.18.1.159

Berkes, F., J. Colding, and C. Folke. 2003. Navigating socialecological systems: Building resilience for complexity and change. Cambridge University Press, Cambridge, United Kingdom. https://doi.org/10.1017/CBO9780511541957

Bestelmeyer, B. T., A. Ash, J. R. Brown, B. Densambuu, M. Fernández-Giménez, J. Johanson, M. Levi, D. Lopez, R. Peinetti, L. Rumpff, and P. Shaver. 2017. State and transition models: Theory, applications, and challenges. Pages 303-345 in B. T. Bestelmeyer, editor. Rangeland Systems. Springer, Cham, Switzerland. https://doi.org/10.1007/978-3-319-46709-2_9

Beyers, J. L. 2004. Postfire seeding for erosion control: Effectiveness and impacts on native plant communities. Conservation Biology 18(4):947-956. https://doi.org/10.1111/ j.1523-1739.2004.00523.x

Brown, P. M., and C. H. Sieg. 1999. Historical variability in fire at the ponderosa pine - Northern Great Plains prairie ecotone, southeastern Black Hills, South Dakota. Écoscience 6(4):539-547. https://doi.org/10.1080/11956860.1999.11682563

Buckland, S. T., D. R. Anderson, K. P. Burnham, J. L. Laake, D. L. Borchers, and L. Thomas. 2001. Introduction to distance sampling estimating abundance of biological populations. Oxford University Press, New York, NY, USA.

Castro, J., C. D. Allen, M. Molina-Morales, S. Marañón-Jiménez, Á. Sánchez-Miranda, and R. Zamora. 2011. Salvage logging versus the use of burnt wood as a nurse object to promote post- 
fire tree seedling establishment. Restoration Ecology 19 (4):537-544. https://doi.org/10.1111/j.1526-100x.2009.00619.x

Caudle, D. 2013. Interagency ecological site handbook for rangelands. US Department of the Interior, Bureau of Land Management, Washington, DC, USA.

Cumming, G. S., and G. D. Peterson. 2017. Unifying research on social-ecological resilience and collapse. Trends in ecology \& evolution 32(9):695-713. https://doi.org/10.1016/j.tree.2017.06.014

Daubenmire, R. F. 1959. A canopy coverage method of vegetational analysis. Northwest Science 33:43-64.

DellaSala, D. A., J. R. Karr, T. Schoennagel, D. Perry, R. F. Noss, D. Lindenmayer, R. Beschta, R. L. Hutto, M. E. Swanson, and J. Evans. 2006. Post-Fire logging debate ignores many issues. Science 314(5796):51-52. https://doi.org/10.1126/science.314.5796.51b

Donovan, V. M., C. P. Roberts, C. L. Wonkka, D. A. Wedin, and D. Twidwell. 2019. Ponderosa pine regeneration, wildland fuels management, and habitat conservation: identifying trade-offs following wildfire. Forests 10(3):286. https://doi.org/10.3390/ $\underline{\text { f10030286 }}$

Flanders, A. A., W. P. Kuvlesky Jr, D. C. Ruthven III, R. E. Zaiglin, R. L. Bingham, T. E. Fulbright, F. Hernández, and L. A. Brennan. 2006. Effects of invasive exotic grasses on south Texas rangeland breeding birds. The Auk 123(1):171-182. https://doi. org/10.1093/auk/123.1.171

Folke, C., S. Carpenter, B. Walker, M. Scheffer, T. Elmqvist, L. Gunderson, and C. S. Holling. 2004. Regime shifts, resilience, and biodiversity in ecosystem management. Annual Review Ecology, Evolution, and Systematics 35:557-581. https://doi.org/10.1146/ annurev.ecolsys.35.021103.105711

Fraver, S., T. Jain, J. B. Bradford, A. W. D’Amato, D. Kastendick, B. Palik, D. Shinneman, and J. Stanovick. 2011. The efficacy of salvage logging in reducing subsequent fire severity in coniferdominated forests of Minnesota, USA. Ecological Applications 21(6):1895-1901. https://doi.org/10.1890/11-0380.1

Gibson, C. M., M. R. Turetsky, K. Cottenie, E. S. Kane, G. Houle, and E. S. Kasischke. 2016. Variation in plant community composition and vegetation carbon pools a decade following a severe fire season in interior Alaska. Journal of Vegetation Science 27(6):1187-1197. https://doi.org/10.1111/jvs.12443

Goheen, J. R., D. J. Augustine, K. E. Veblen, D. M. Kimuyu, T. M. Palmer, L. M. Porensky, R. M. Pringle, J. Ratnam, C. Riginos, M. Sankaran, A. T. Ford, A. A. Hassan, R. Jakopak, T. R. Kartzinel, S. Kurukura, A. M. Louthan, W. O. Odadi, T. O. Otieno, A. M. Wambua, H. S. Young, and T. P. Young. 2018. Conservation lessons from large-mammal manipulations in East African savannas: the KLEE, UHURU, and GLADE experiments. Annals of the New York Academy of Sciences 1429 (1): 31-49. https://doi.org/10.1111/nyas.13848

Grant, C. D. 2006. State-and-transition successional model for bauxite mining rehabilitation in the Jarrah Forest of western Australia. Restoration Ecology 14(1):28-37. https://doi. org/10.1111/j.1526-100X.2006.00102.X
Gunderson, L. H., and C. S. Holling. 2002. Panarchy: Understanding transformations in human and natural systems. Island Press, Washington, DC.

Harmon, M. E., J. F. Franklin, F. J. Swanson, P. Sollins, S. V. Gregory, J. D. Lattin, N. H. Anderson, S. P. Cline, N. G. Aumen, J. R. Sedell, G. W. Lienkaemper, K. Cromack, and K. W. Cummins. 1986. Ecology of coarse woody debris in temperate ecosystems. Pages 59-234 in A. MacFadyen and E. D. Ford, editors. Advances in Ecological Research. Academic Press, London, England. https://doi.org/10.1016/s0065-2504(03)34002-4

Heinselman, M. L. 1981. Fire and succession in the conifer forests of northern North America. Pages 374-405 Forest succession: concepts and applications. Springer, New York, NY. https://doi. org/10.1007/978-1-4612-5950-3 23

Hiers, J. K., S. T. Jackson, R. J. Hobbs, E. S. Bernhardt, and L. E. Valentine. 2016. The precision problem in conservation and restoration. Trends in Ecology \& Evolution 31(11):820-830. https:// doi.org/10.1016/j.tree.2016.08.001

Holling, C. S. 1973. Resilience and stability of ecological systems. Annual Review of Ecology and Systematics 4(1):1-23. https://doi. org/10.1146/annurev.es.04.110173.000245

Holling, C. S. 1986. Resilience of terrestrial ecosystems: local surprise and global change. Pages 292-320 in W. C. Clark and R. E. Munn, editors. Sustainable Development of the Biosphere. Cambridge University Press, Cambridge.

Holling, C. S., and G. K. Meffe. 1996. Command and control and the pathology of natural resource management. Conservation Biology 10(2):328-337. https://doi.org/10.1046/j.1523-1739.1996.10020328. $\underline{\mathrm{X}}$

Hovick, T. J., J. R. Miller, S. J. Dinsmore, D. M. Engle, D. M. Debinski, and S. D. Fuhlendorf. 2011. Effects of fire and grazing on grasshopper sparrow nest survival. The Journal of Wildlife Management 76(1):19-27. https://doi.org/10.1002/jwmg.243

Huff, M., K. Bettinger, H. Ferguson, M. Brown, and B. Altman. 2000. A habitat-based point-count protocol for terrestrial birds, emphasizing Washington and Oregon. Page 39. U.S. Department of Agriculture, Forest Service, Pacific Northwest Research Station, Portland, OR. https://doi.org/10.2737/PNW-GTR-501

Hutto, R. L., M. L. Bond, and D. A. DellaSala. 2015. Using bird ecology to learn about the benefits of severe fire. Pages 55-88 in D. A. DellaSala and C. T. Hanson, editors. The Ecological Importance of Mixed-Severity Fires: Natures Phoenix. Elsevier, Amsterdam, Netherlands. https://doi.org/10.1016/ B978-0-12-802749-3.00003-7

Hutto, R. L., and S. M. Gallo. 2006. The effects of postfire salvage logging on cavity-nesting birds. The Condor 108(4):817-831. https://doi.org/10.1093/condor/108.4.817

Johnstone, J. F., C. D. Allen, J. F. Franklin, L. E. Frelich, B. J. Harvey, P. E. Higuera, M. C. Mack, R. K. Meentemeyer, M. R. Metz, G. L. Perry, T. Schoennagel, and M. G. Turner. 2016. Changing disturbance regimes, ecological memory, and forest resilience. Frontiers in Ecology and the Environment 14(7):369-378. https://doi.org/10.1002/fee.1311 
Jones, M. O., B. W. Allred, D. E. Naugle, J. D. Maestas, P. Donnelly, L. J. Metz, J. Karl, R. Smith, B. Bestelmeyer, C. Boyd, J. D. Kerby, and J. D. McIver. 2018. Innovation in rangeland monitoring: annual, $30 \mathrm{~m}$, plant functional type percent cover maps for U.S. rangelands, 1984-2017. Ecosphere 9(9):e02430. https://doi.org/10.1002/ecs2.2430

Keele, E. C., V. M. Donovan, C. P. Roberts, S. M. Nodskov, C. L. Wonkka, C. R. Allen, L. A. Powell, D. A. Wedin, D. G. Angeler, and D. Twidwell. 2019. Relationships between wildfire burn severity, cavity-nesting bird assemblages, and habitat in an eastern ponderosa pine forest. The American Midland Naturalist 181 (1):1-17. https://doi.org/10.1674/0003-0031-181.1.1

Kroll, A. J., Y. Ren, J. E. Jones, J. Giovanini, R. W. Perry, R. E. Thill, D. White, and T. B. Wigley. 2014. Avian community composition associated with interactions between local and landscape habitat attributes. Forest Ecology and Management 326:46-57. https://doi.org/10.1016/j.foreco.2014.04.011

Legendre, P., and E. D. Gallagher. 2001. Ecologically meaningful transformations for ordination of species data. Oecologia 129 (2):271-280. https://doi.org/10.1007/s004420100716

Lindenmayer, D. B., P. J. Burton, and J. F. Franklin. 2008. Salvage logging and its ecological consequences. Island Press, Washington, DC.

Lindenmayer, D. B., D. R. Foster, J. F. Franklin, M. L. Hunter, R. F. Noss, F. A. Schmiegelow, and D. Perry. 2004. Salvage harvesting policies after natural disturbance. Science 303 (5662):1303-1303. https://doi.org/10.1126/science.1093438

Mills, T. R., M. A. Rumble, and L. D. Flake. 2000. Habitat of birds in ponderosa pine and aspen/birch forest in the Black Hills, South Dakota. Journal of Field Ornithology 71(2):187-206. https://doi.org/10.1648/0273-8570-71.2.187

Noss, R. F., J. F. Franklin, W. L. Baker, T. Schoennagel, and P. B. Moyle. 2006. Managing fire-prone forests in the western United States. Frontiers in Ecology and the Environment 4(9):481-487. https://doi.org/10.1890/1540-9295(2006)4[481:MFFITW]2.0.CO;2

Odion, D. C., M. A. Moritz, and D. A. DellaSala. 2010. Alternative community states maintained by fire in the Klamath Mountains, USA. Journal of Ecology 98(1):96-105. https://doi. org/10.1111/j.1365-2745.2009.01597.x

Oksanen, J., F. G. Blanchet, M. Friendly, R. Kindt, P. Legendr, D. McGlinn, P. R. Minchin, R. B. O’Hara, G. L. Simpson, P. Solymos, M. H. H. Stevens, E. Szoecs, and H. Wagner. 2016. : community ecology package. $\mathrm{R}$ package version $2.4-1$. https:// CRAN.R-project.org/package $=$ vegan

Ostfeld, R. S., and F. Keesing. 2000. Pulsed resources and community dynamics of consumers in terrestrial ecosystems. Trends in Ecology \& Evolution 15(6):232-237. https://doi. org/10.1016/S0169-5347(00)01862-0

Perry, D. A., P. F. Hessburg, C. N. Skinner, T. A. Spies, S. L. Stephens, A. H. Taylor, J. F. Franklin, B. McComb, and G. Riegel. 2011. The ecology of mixed severity fire regimes in Washington, Oregon, and Northern California. Forest Ecology and Management 262(5):703-717. https://doi.org/10.1016/j.foreco.2011.05.004
Pilz, D., N. S. Weber, M. C. Carter, C. G. Parks, and R. Molina. 2004. Productivity and diversity of morel mushrooms in healthy, burned, and insect-damaged forests of northeastern Oregon. Forest Ecology and Management 198(1-3):367-386. https://doi. org/10.1016/j.foreco.2004.05.028

Porensky, L. M., K. E. Mueller, D. J. Augustine, and J. D. Derner. 2016. Thresholds and gradients in a semi-arid grassland: longterm grazing treatments induce slow, continuous and reversible vegetation change. Journal of Applied Ecology 53(4):1013-1022. https://doi.org/10.1111/1365-2664.12630

Riffell, S., J. Verschuyl, D. Miller, and T. B. Wigley. 2011. Biofuel harvests, coarse woody debris, and biodiversity - A meta-analysis. Forest Ecology and Management 261(4):878-887. https://doi. org/10.1016/j.foreco.2010.12.021

Roberts, C. P., V. M. Donovan, C. L. Wonkka, L. A. Powell, C. R. Allen, D. G. Angeler, D. Wedin, and D. Twidwell. 2019. Fire legacies in eastern ponderosa pine forests. Ecology and Evolution 9(5469):1-11. https://doi.org/10.1002/ece3.4879

Robichaud, P. R., L. E. Ashmun, and B. D. Sims. 2010. Post-fire treatment effectiveness for hill-slope stabilization. Page 62. US Department of Agriculture, Forest Service, Rocky Mountain Research Station, Fort Collins, CO. https://doi.org/10.2737/rmrsgtr-240

Rocha, J. C., G. D. Peterson, and R. Biggs. 2015. Regime shifts in the Anthropocene: drivers, risks, and resilience. PLOS ONE 10(8): e0134639. https://doi.org/10.1371/journal.pone.0134639

Scheffer, M., S. Carpenter, J. A. Foley, C. Folke, and B. Walker. 2001. Catastrophic shifts in ecosystems. Nature 413 (6856):591-596. https://doi.org/10.1038/35098000

Schneider, R., K. Stoner, G. Steinauer, M. Panella, and M. Humpert. 2011. The Nebraska natural legacy project: state wildlife action plan. Nebraska Game and Parks Commission, Lincoln, NE.

Seidl, R., W. Rammer, and T. A. Spies. 2014. Disturbance legacies increase the resilience of forest ecosystem structure, composition, and functioning. Ecological Applications 24(8):2063-2077. https:// doi.org/10.1890/14-0255.1

Sliwinski, M., L. Powell, N. Koper, M. Giovanni, and W. Schacht. 2016. Research design considerations to ensure detection of all species in an avian community. Methods in Ecology and Evolution 7(4):456-462. https://doi.org/10.1111/2041-210X.12506

Sundstrom, S. M., and C. R. Allen. 2019. The adaptive cycle: More than metaphor. Ecological Complexity 39:100767. https:// doi.org/10.1016/j.ecocom.2019.100767

Swanson, M. E., J. F. Franklin, R. L. Beschta, C. M. Crisafulli, D. A. DellaSala, R. L. Hutto, D. B. Lindenmayer, and F. J. Swanson. 2010. The forgotten stage of forest succession: earlysuccessional ecosystems on forest sites. Frontiers in Ecology and the Environment 9(2):117-125. https://doi.org/10.1890/090157

Turner, M. G., W. L. Baker, C. J. Peterson, and R. K. Peet. 1998. Factors influencing succession: lessons from large, infrequent natural disturbances. Ecosystems 1(6):511-523. https://doi. org/10.1007/s100219900047 
Twidwell, D., B. W. Allred, and S. D. Fuhlendorf. 2013. Nationalscale assessment of ecological content in the world's largest land management framework. Ecosphere 4(8):1-27.

USDA Natural Resource Conservation Service. 2006. Land Resource Regions and Major Land Resource Areas of the United States, the Caribbean, and the Pacific Basin. Page 682. U.S. Department of Agriculture Handbook 296, Natural Resource Conservation Service, Washington, D.C.

USDA Forest Service. 2007. Managing forests after fire. Page 12. Pacific Northwest Research Station, USA Forest Service, Portland, OR.

USDA Forest Service. 2015. Forest Stewardship Program: National Standards and Guidelines. U.S. Department of Agriculture, Forest Service, State and Private Forestry, Cooperative Forestry, Washington, DC.

Westoby, M., B. Walker, and I. Noy-Meir. 1989. Opportunistic management for rangelands not at equilibrium. Journal of Range Management 42(4):266-274.

Whittle, C. A., L. C. Duchesne, and T. Needham. 1997. The impact of broadcast burning and fire severity on species composition and abundance of surface vegetation in a jack pine (Pinus banksiana) clear-cut. Forest Ecology and Management 94(1):141-148. https:// doi.org/10.1016/S0378-1127(96)03969-2

Wong, N. K., J. W. Morgan, and J. Dorrough. 2010. A conceptual model of plant community changes following cessation of cultivation in semi-arid grassland. Applied Vegetation Science 13 (4):389-402. https://doi.org/10.1111/j.1654-109X.2010.01080.x

Woodcock, D. W. 1992. The rain on the plain: Are there vegetation-climate feedbacks? Global and Planetary Change 5 (3):191-201. https://doi.org/10.1016/0921-8181(92)90010-8 


\section{Appendix 1:}

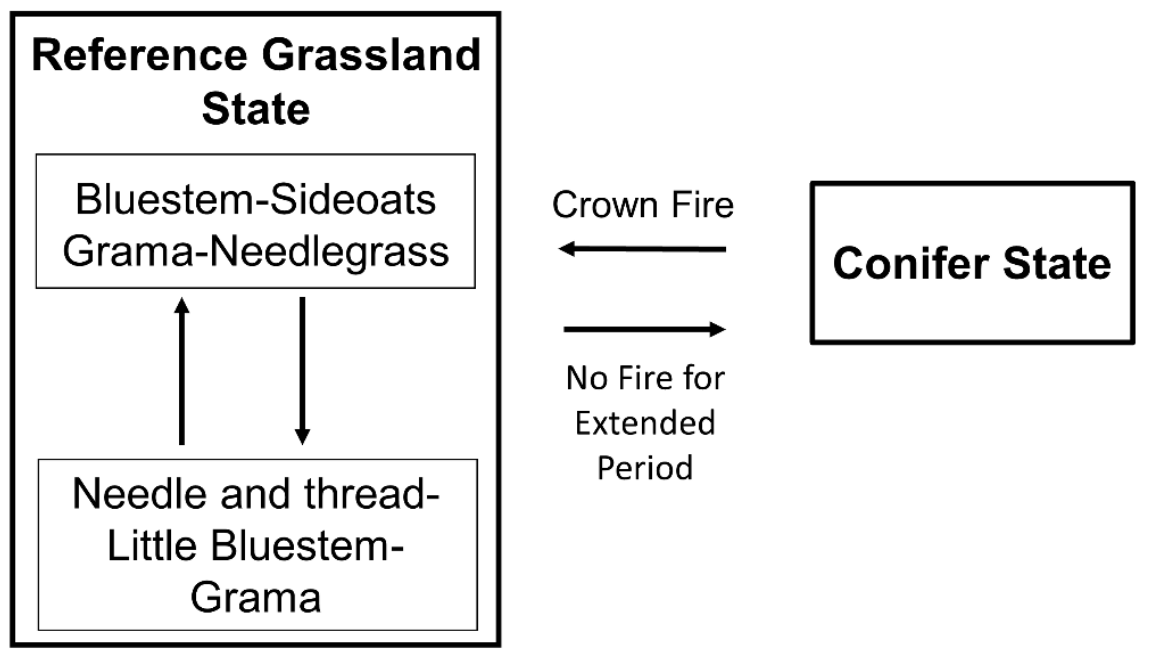

Figure A1.1. A simplified state-and-transition model (STM) from the USDA Ecological Site Descriptions for the 'Shallow' ecological site in the Mixed Sandy and Silty Tableland and Badlands Major Labe Resource Area before its alteration in 2019. The STM has been simplified to only highlight the role of fire. Bold outlined boxes denote alternative ecological regimes (also termed states). Arrows represent a transition between ecosystem states (bold boxes) or community phases (light boxes). Words next to arrows represent where fire is a proposed driver of transition. 


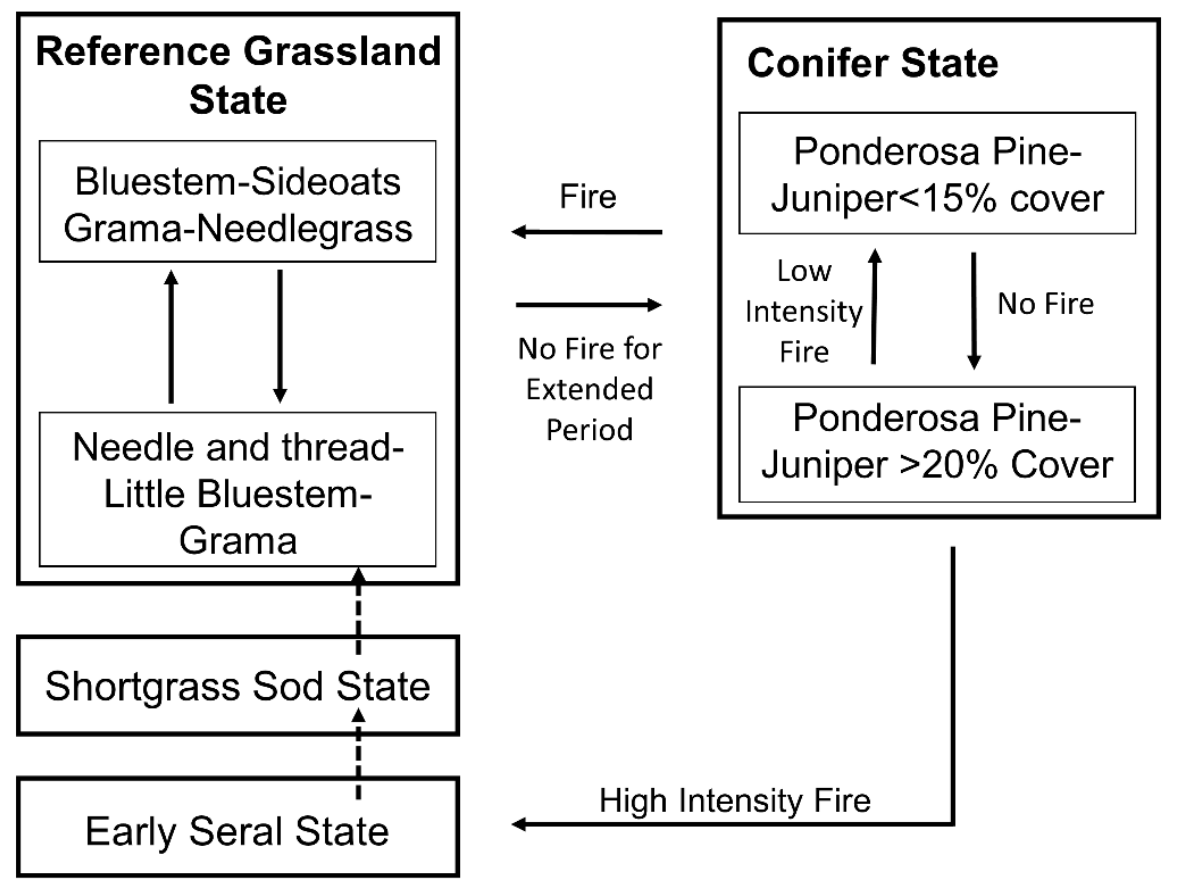

Figure A1.2. A simplified state-and-transition model (STM) from the USDA Ecological Site Descriptions for the 'Shallow' ecological site in the Mixed Sandy and Silty Tableland and Badlands Major Labe Resource Area following its update in 2019. The STM has been simplified to only highlight the role of fire. Bold outlined boxes denote alternative ecological regimes (also termed states). Continuous arrows represent a transition between ecosystem states (bold boxes) or community phases (light boxes). Dotted arrows represent where recovery may not be fast. Words next to arrows represent where fire is a proposed driver of transition. 


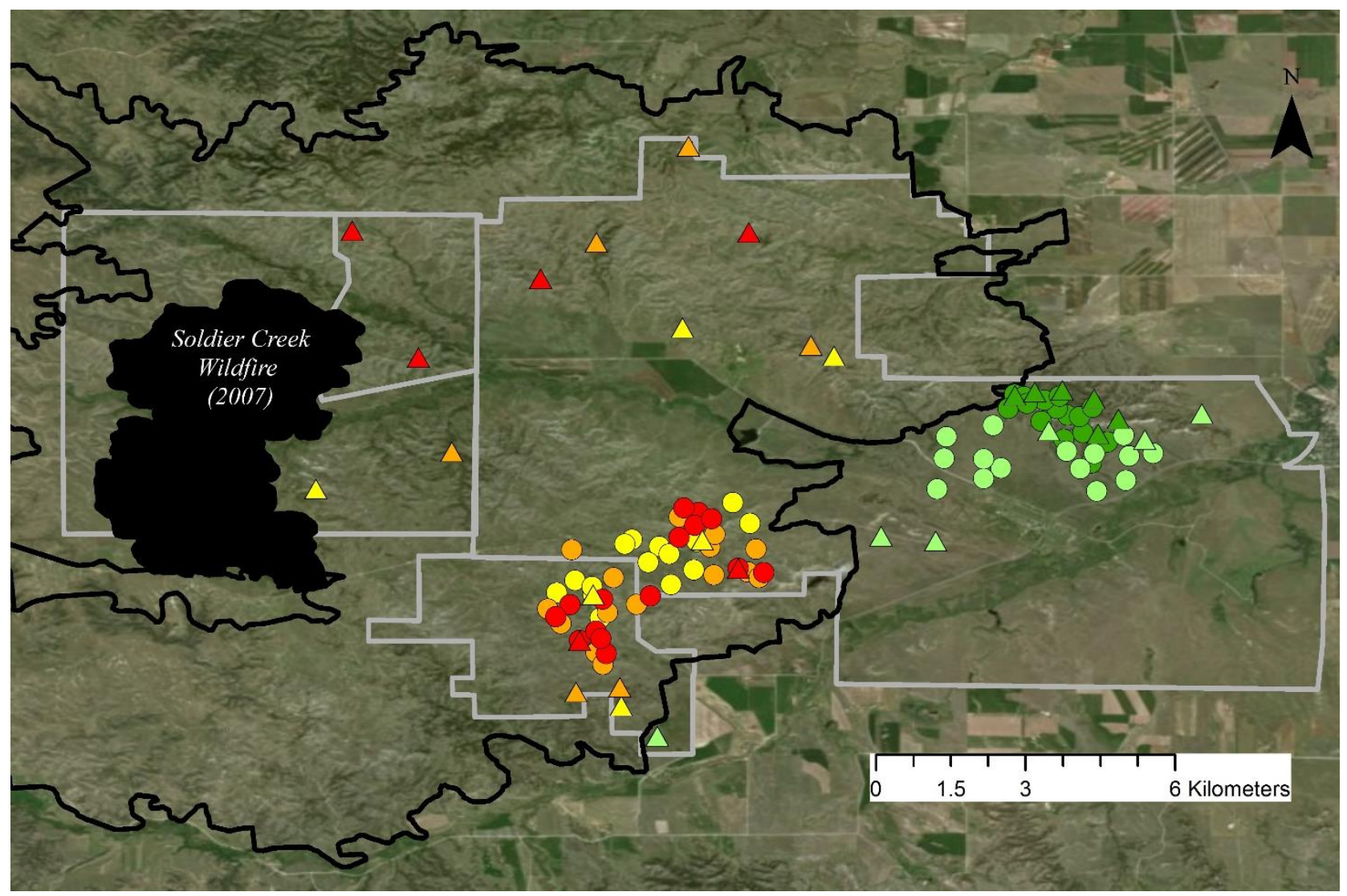

Figure A1.3. A map of the 1989 Fort Robinson wildfire perimeter (outlined in black) with sampling sites for bird community, understory woody plant community, and stand structural characteristics represented by circles, and herbaceous community sample sites represented by triangles. Dark green symbols represent unburned forest sites, orange symbols represent forests that burned at low severity and are expected to have the same identity as unburned forest, red symbols represent forests that burned at high severity and are expected to have the same identity as unburned grassland, yellow symbols represent grasslands that burned and are expected to have the same identity as unburned grasslands, and light green symbols represent unburned grasslands. Public land perimeters we sampled in are outlined in grey. The soldier creek wildfire perimeter, marked in black, was excluded from sampling. 


\section{Tables}

Table A1.1. Eigenvalues and the proportion of explained variation that was represented by RDA1 and RDA2 in two redundancy analyses on community and structural data collected in 2015 and 2016 within and surrounding the perimeter of the 1989 Fort Robinson wildfire, Nebraska, USA across a range of transition classes. Transition classes were used as predictor variables and were composted of fire severity (unburned, low severity, or high severity) and the ecological regime (grassland or forest) that occurred prior to the fire. Italicized titles represent the data used in redundancy analyses, where "Herbaceous Community" indicates RDA outputs with herbaceous plant community data and "Additional Ecosystem Characteristics" indicates RDA outputs with understory woody plant height and cover, bird species presence, coarse woody debris cover, and snag DBH.

\begin{tabular}{lll}
\hline & Eigenvalue & Proportion Explained \\
\hline Herbaceous & Community \\
\hline RDA1 & 0.03 & 0.63 \\
RDA2 & 0.01 & 0.23 \\
\hline Additional Ecosystem & Characteristics \\
\hline RDA1 & 0.13 & 0.57 \\
RDA2 & 0.05 & 0.21 \\
\hline
\end{tabular}


Table A1.2. Inertia and the proportion of inertia that was constrained versus unconstrained in two redundancy analyses on community and structural data collected in 2015 and 2016 within and surrounding the perimeter of the 1989 Fort Robinson wildfire, Nebraska, USA across a range of transition classes. Transition classes were used as predictor variables and were composted of fire severity (unburned, low severity, or high severity) and the ecological regime (grassland or forest) that occurred prior to the fire. Italicized titles represent the data used in redundancy analyses, where "Herbaceous Community" indicates RDA outputs with herbaceous plant community data and "Additional Ecosystem Characteristics" indicates RDA outputs with understory woody plant height and cover, bird species presence, coarse woody debris cover, and snag DBH.

\begin{tabular}{lll}
\hline & Inertia & Proportion of Inertia \\
\hline Herbaceous Community & & \\
\hline Constrained & 0.05 & 0.24 \\
Unconstrained & 0.17 & 0.76 \\
\hline Additional Ecosystem Characteristics & \\
\hline Constrained & 0.23 & 0.23 \\
Unconstrained & 0.76 & 0.76 \\
\hline
\end{tabular}


Table A1.3. A list of species codes, species names, and common names of herbaceous vegetation that was recorded within and surrounding the perimeter of the 1989 Fort Robinson wildfire, Nebraska, USA.

\begin{tabular}{|c|c|c|}
\hline Species Code & Species & Common Name \\
\hline ACMI & Achillea millefolium & Common yarrow \\
\hline ALTE & Allium textile & Prairie Onion \\
\hline ALDE & Alyssum desertorum & Desert madwort \\
\hline AMPS & Ambrosia psilostachya & Cuman ragweed \\
\hline ANMA & Anaphalis margaritacea & Western pearly everlasting \\
\hline ANGE & Andropogon gerardii & Big bluestem \\
\hline ANHA & Andropogon hallii & Sand bluestem \\
\hline ANCY & Anemone cylindrica & Candle anemone \\
\hline ANPA & Antennaria parvifolia & Small-leaf pussytoes \\
\hline ARHI & Arabis hirsuta & Hairy rockcress \\
\hline ARPU & Aristida purpurea & Purple threeawn \\
\hline ARDR & Artemisia dracunculoides & Tarragon \\
\hline ARFI & Artemisia filifolia & Sand sagebrush \\
\hline ARFR & Artemisia frigida & Prairie Sagewort \\
\hline ARLU & Artemisia ludoviciana & White sagebrush \\
\hline ASPU & Asclepias pumila & Plains milkweed \\
\hline ASFA & Aster falcatus & White prairie aster \\
\hline ASLA & Aster laevis & Smooth blue aster \\
\hline ASOB & Aster oblongifolia & Aromatic aster \\
\hline ASCR & Astragalus crassicarpus & Groundplum Milkvetch \\
\hline ASGR & Astragalus gracilis & Slender milkvetch \\
\hline
\end{tabular}




\begin{tabular}{|c|c|c|}
\hline ASLA & Astragalus laxmannii & Laxmann's milkvetch \\
\hline ASLO & Astragalus lotiflorus & Lotus milkweed \\
\hline ASMI & Astragalus missouriensis & Missouri milkvetch \\
\hline BG & Bare ground & Bare Ground \\
\hline MARE & Berberis repens & Creeping barberry \\
\hline BEWY & Besseya wyomingensis & Wyoming besseya \\
\hline $\mathrm{BOHO}$ & Boechera hoboellii & Holbøll's rockcress \\
\hline BOCU & Bouteloua curtipendula & Sideoats grama \\
\hline BOGR & Bouteloua gracilis & Blue grama \\
\hline $\mathrm{BOHI}$ & Bouteloua hirsuta & Hairy grama \\
\hline BREU & Brickellia eupatorioides & False boneset \\
\hline BRIN & Bromus inermis & Smooth brome \\
\hline BRTE & Bromus japonicus/tectorum & Cheatgrass \\
\hline CALO & Calamovilfa longifolia & Prairie Sandreed \\
\hline CANU & Calochortus nuttallii & Sego lily \\
\hline CASE & Calylophus serrulatus & Yellow sundrops \\
\hline CAMI & Camelina microcarpa & Littlepod false flax \\
\hline CARO & Campanula rotundifolia & Bluebell bellflower \\
\hline CADU & Carex eleocharis & Needlelead sedge \\
\hline CAFI & Carex filifolia & Threadleaf sedge \\
\hline CAIN & Carex heliophila & Sun sedge \\
\hline CASA & Carex saximontana & Rocky Mountain sedge \\
\hline CEAR & Cerastium arvense & Field chickweed \\
\hline CHPR & Chenopodium pratericola & Desert goosefoot \\
\hline CIAR & Cirsium arvense & Canada thistle \\
\hline
\end{tabular}




\begin{tabular}{lll} 
CIPL & Cirsium plattensis & Platte thistle \\
CIUN & Cirsium undulatum & Wavyleaf thistle \\
COUM & Comandra umbellata & Bastard toadflax \\
COCA & Conyza canadensis & Canadian horseweed \\
CRTE & Croton texensis & Texas Croton \\
CYOF & Cynoglossum officinale & Gypsyflower \\
CYFR & Cystopteris fragilis & Brittle bladderfern \\
DACA & Dalea candida & White prairie clover \\
DAPU & Dalea purpurea & Purple prairie clover \\
DEPI & Descurainia pinnata & Western tansymustard \\
DRRE & Draba reptans & Carolina draba \\
ECPU & Echinacea purpurea & Eastern purple coneflower \\
ELCA & Elymus canadensis & Canada wildrye \\
ELLA & Elymus lanceolatus & Thickspike wheatgrass \\
ELSM & Elymus smithii & Western wheatgrass \\
ELTR & Elymus trachycaulus & Slender wheatgrass \\
ELVI & Elymus villosus & Hairy wildrye \\
ERHO & Eremogone hookeri & Hooker's sandwort \\
ERST & Erigeron strigosus & Prairie fleabane \\
ERAN & Eriogonum annuum & Annual buckwheat \\
ERCE & Eriogonum cernuum & Nodding buckwheat \\
ERAS & Erysimum asperum & Western wallflower \\
ERCH & Erysimum cheiranthoides & Wormseed wallflower \\
EUGL & Euphorbia glyptosperma & Ribseed sandmat \\
EUMI & Euphorbia missurica & Prairie sandmat \\
\hline
\end{tabular}




$\begin{array}{lll}\text { EUBR } & \text { Euphorbia robusta } & \text { Horned spurge } \\ \text { GAAP } & \text { Galium aparine } & \text { Stickywilly } \\ \text { GABO } & \text { Galium boreale } & \text { Northern bedstraw } \\ \text { GATR } & \text { Galium triflorum } & \text { Fragrant bedstraw } \\ \text { OESU } & \text { Gaura coccinea } & \text { Scarlet beeblossom } \\ \text { GLLE } & \text { Glycyrrhiza lepidota } & \text { American licorice } \\ \text { GNPA } & \text { Gnaphalium palustre } & \text { Western marsh cudweed } \\ \text { GUSA } & \text { Gutierrezia sarothrae } & \text { Broom snakeweed } \\ \text { HEHI } & \text { Hedeoma hispida } & \text { Rough false pennyroyal } \\ \text { HEPE } & \text { Helianthus petiolaris } & \text { Prairie sunflower } \\ \text { HECO } & \text { Hesperostipa comata } & \text { Needle and threat } \\ \text { HEVI4 } & \text { Heterotheca villosa } & \text { Hairy goldenaster } \\ \text { HERI } & \text { Heuchera richardsonii } & \text { Richardson's alumroot } \\ \text { HIUM } & \text { Hieracium umbellatum } & \text { Narrowleaf hawkweed } \\ \text { IPLE } & \text { Ipomoea leptophylla } & \text { Bush morning-glory } \\ \text { KOMA } & \text { Koeleria macrantha } & \text { Prairie junegrass } \\ \text { LALU } & \text { Lactuca ludoviciana } & \text { Biannual lettuce } \\ \text { LASE } & \text { Lactuca serriola } & \text { Prickly lettuce } \\ \text { LATA } & \text { Lactuca tatarica } & \text { Blue lettuce } \\ \text { LAPO } & \text { Lathyrus polymorphus } & \text { Manystem pea } \\ \text { LEAR } & \text { Lesquerella arenosa } & \text { Great Plains bladderpod } \\ \text { LELU } & \text { Lesquerella ludoviciana } & \text { Foothill bladderpod } \\ \text { LIPU } & \text { Liatris punctata } & \text { Dotted blazing star } \\ \text { LIRI } & \text { Linum rigidum } & \text { Stiffstem flax } \\ \text { LIIN } & \text { Lithospermum incisum } & \text { Narrowleaf stoneseed }\end{array}$




\begin{tabular}{|c|c|c|}
\hline LITTER & Litter & Litter \\
\hline LOOR & Lomatium orientale & Northern Idaho biscuitroot \\
\hline LUPL & Lupinus plattensis & Nebraska lupine \\
\hline LYJU & Lygodesmia juncea & Rush Skeletonplant \\
\hline MATA & Machaeranthera tanacetifolia & Tanseyleaf tansyaster \\
\hline MAST & Maianthemum stellatum & Starry false lily of the valley \\
\hline MEOF & Melilotus officinalis & Sweetclover \\
\hline MIHI & Mirabilis hirsuta & Hairy four o'clock \\
\hline MILI3 & Mirabilis linearis & Narrowleaf four o'clock \\
\hline MOPE & Monarda pectinata & Pony beebalm \\
\hline NAVI & Nassella viridula & Green needlegrass \\
\hline OPFR & Opuntia fragilis & Brittle pricklypear \\
\hline OPHU & Opuntia humifusa & Devil's-tongue \\
\hline OXLA & Oxytropis lambertii & Purple locoweed \\
\hline PACA & Panicum capillare & Witchgrass \\
\hline PAOL & Panicum oligosanthes & Scribner's panic grass \\
\hline DIWI & Panicum wilcoxianum & Fall rosette grass \\
\hline PEAR & Pediomelum argophyllum & Silverleaf Indian breadroot \\
\hline PEES & Pediomelum esculentum & Large Indian beadroot \\
\hline PEAL & Penstemon albidus & White penstemon \\
\hline PEAN & Penstemon angustifolius & Broadbeard beardtongue \\
\hline PEGR & Penstemon gracilis & Lilac penstemon \\
\hline PEGRA & Penstemon grandiflorus & Large beardtongue \\
\hline PHAN & Phlox andicola & Prairie phlox \\
\hline PHHO & Phlox hoodii & Spiny phlox \\
\hline
\end{tabular}




\begin{tabular}{lll} 
PHHI & Physalis hispida & Prairie groundcherry \\
PHLO & Physalis longifolia & Longleaf groundcherry \\
PIPO & Pinus ponderosa & Ponderosa pine \\
PIMI & Piptatherum micranthum & Littleseed ricegrass \\
PLPA & Plantago patagonica & Woolly plantain \\
POFE & Poafendleri & Muttongrass \\
POPR & Poa pratensis & Kentucky bluegrass \\
POPE & Potentilla pensylvanica & Pennsylvania cinquefoil \\
PRVI & Prunus virginiana & Chokecherry \\
PSLA & Psoralidium lanceolatum & Lemon scurfpea \\
PSTE & Psoralidium tenuiflorum & Slimflower scurfpea \\
PUPA & Pulsatilla patens & Eastern pasqueflower \\
RACO & Ratibida columnifera & Upright prairie coneflower \\
RHTR & Rhus trilobata & Skunkbush sumac \\
RIBES & Ribes sp. & Currant \\
ROCK & Rock & Rock \\
ROAR & Rosa arkansana & Prairie rose \\
ROWO & Rosa woodsii & Woods' rose \\
SCSC & Schizachyrium scoparium & Little bluestem \\
SEIN & Senecio integerrimus & Lambstongue ragwort \\
SEPL & Senecio plattensis & Praire groundsel \\
SIMO & Sisyrinchium montanum & Strict blue-eyed grass \\
SOCA & Solidago canadensis & Canadian goldenrod \\
SOMI & Solidago missouriensis & Missouri goldenrod \\
SOMO & Solidago mollis & Velvety goldenrod \\
\hline
\end{tabular}




\begin{tabular}{lll} 
SORI & Solidago rigida & Stiff goldenrod \\
SPCO & Sphaeralcea coccinea & Scarlet globemallow \\
SPCOM & Sporobolus compositus & Composite dropseed \\
SPCR & Sporobolus cryptandrus & Sand dropseed \\
SYOC & Symphoricarpos occidentalis & Western snowberry \\
TAOF & Taraxacum officinale & Common dandelion \\
THRH & Thermopsis rhombifolia & Prairie thermopsis \\
TORY & Toxicodendron rydbergii & Western poison ivy \\
TROC & Tradescantia occidentalis & Prairie spiderword \\
TRDU & Tragopogon dubius & Yellow salsify \\
VETH & Verbascum thapsus & Common mullein \\
VEST & Verbena stricta & Hoary verbena \\
VINU & Viola nuttallii & Nuttall's violet \\
VIRI & Vitis riparia & Riverbank grape \\
VUOC & Vulpia octoflora & Sixweeks fescue \\
XASP & Xanthisma spinulosum & Sping goldenbush \\
YUGL & Yucca glauca & Soapweed yucca \\
ZIVE & Zigadenus venenosus & Meadow deathcamas \\
\hline
\end{tabular}


Table A1.4. A list of species codes, species name, and common names used in the "Additional Ecosystem Characteristics' ordination that were found in 2016 within and surrounding the perimeter of the 1989 Fort Robinson wildfire, Nebraska, USA.

\begin{tabular}{|c|c|c|}
\hline Species Codes & Species & Common Name \\
\hline CWD & Coarse Woody Debris & Coarse Woody Debris \\
\hline Snag_DBH & Snag Diameter at Breast Height & Snag Diameter at Breast Height \\
\hline Snag_Density & Snag Density & Snag Density \\
\hline AMGO & Spinus tristis & American Goldfinch \\
\hline AMRO & Turdus migratorius & American Robin \\
\hline AUWA & Setophaga coronata auduboni & Audubon's Warbler \\
\hline $\mathrm{BCCH}$ & Poecile atricapillus & Black-capped Chickadee \\
\hline BGGN & Polioptila caerulea & Blue-gray Gnatcatcher \\
\hline $\mathrm{BHCO}$ & Molothrus ater & Brown-headed Cowbird \\
\hline BHGR & Pheucticus melanocephalus & Back-headed Grosbeak \\
\hline BRBL & Euphagus cyanocephalus & Brewer's Blackbird \\
\hline BRTH & Toxostoma rufum & Brown Thrasher \\
\hline BUOR & Icterus bullockii & Bullock's Oriole \\
\hline CAKI & Tyrannus vociferans & Cassin's Kingbird \\
\hline CERW & Setophaga cerulea & Cerulean Warbler \\
\hline CHSP & Spizella passerina & Chipping Sparrow \\
\hline CONI & Chordeiles minor & Common Nighthawk \\
\hline EABL & Sialia sialis & Eastern Bluebird \\
\hline EAKI & Euphagus cyanocephalus & Eastern Kingbird \\
\hline GRSP & Ammodramus savannarum & Grasshopper Sparrow \\
\hline
\end{tabular}




\begin{tabular}{|c|c|c|}
\hline HAWO & Dryobates villosus & Hairy Woodpecker \\
\hline HOWR & Troglodytes aedon & House Wren \\
\hline MAKE & Falco sparverius & American Kestrel \\
\hline LASP & Chondestes grammacus & Lark Sparrow \\
\hline MOBL & Sialia currucoides & Mountain Bluebird \\
\hline MODO & Zenaida macroura & Mourning Dove \\
\hline OVEN & Seiurus aurocapilla & Ovenbird \\
\hline PIJA & Gymnorhinus cyanocephalus & Pinyon Jay \\
\hline PLVI & Vireo plumbeus & Plumbeous Vireo \\
\hline PRFA & Falco mexicanus & Prairie Falcon \\
\hline PYNU & Sitta pygmaea & Pygmy Nuthatch \\
\hline RBNU & Sitta canadensis & Red-breasted Nuthatch \\
\hline RHWO & Melanerpes erythrocephalus & Red-headed Woodpecker \\
\hline ROWR & Salpinctes obsoletus & Rock Wren \\
\hline RSTO & Pipilo maculatus & Rufous-sided Towhee \\
\hline BANS & Riparia riparia & Bank Swallow \\
\hline TUVU & Cathartes aura & Turkey Vulture \\
\hline WEKI & Tyrannus verticalis & Western Kingbird \\
\hline WEME & Sturnella neglecta & Western Meadowlark \\
\hline WEWP & Contopus sordidulus & Western Wood-pewee \\
\hline YSFL & Colaptes auratus auratus & Yellow-shafted Flicker \\
\hline ACNE_C & Acer negundo (Cover) & Box elder \\
\hline ACNE_H & Acer negundo (Height) & Box elder \\
\hline ARFI_C & Artemisia filifolia (Cover) & Sand sagebrush \\
\hline ARFI_H & Artemisia filifolia (Height) & Sand sagebrush \\
\hline
\end{tabular}




\begin{tabular}{|c|c|c|}
\hline GUSA_C & Gutierrezia sarothrae (Cover) & Broom snakeweed \\
\hline GUSA_H & Gutierrezia sarothrae (Height) & Broom snakeweed \\
\hline JUNI_C & Juniperus sp. (Cover) & Juniper \\
\hline JUNI_H & Juniperus sp. (Height) & Juniper \\
\hline MARE_C & Mahonia repens (Cover) & Creeping barberry \\
\hline MARE_H & Mahonia repens (Height) & Creeping barberry \\
\hline PP_C & Pinus ponderosa (Cover) & Ponderosa pine \\
\hline PP_H & Pinus ponderosa (Height) & Ponderosa pine \\
\hline PRAM_C & Prunus americana (Cover) & American plum \\
\hline PRAM_H & Prunus americana (Height) & American plum \\
\hline PRVI_C & Prunus virginiana (Cover) & Chokecherry \\
\hline PRVI_H & Prunus virginiana (Height) & Chokecherry \\
\hline RHTR_C & Rhus trilobata (Cover) & Skunkbush \\
\hline RHTR_H & Rhus trilobata (Height) & Skunkbush \\
\hline RIAM_C & Ribes americanum (Cover) & American black currant \\
\hline RIAM_H & Ribes americanum (Height) & American black currant \\
\hline RIAU_C & Ribes aureum (Cover) & Golden current \\
\hline RIAU_H & Ribes aureum (Height) & Golden current \\
\hline RIOD_C & Ribes odoratum (Cover) & Clove current \\
\hline RIOD_H & Ribes odoratum (Height) & Clove current \\
\hline RIOX_C & Ribes oxyacanthoides (Cover) & Canadian gooseberry \\
\hline RIOX_H & Ribes oxyacanthoides (Height) & Canadian gooseberry \\
\hline ROWO_C & Rosa woodsii (Cover) & Woods rose \\
\hline ROWO_H & Rosa woodsii (Height) & Woods rose \\
\hline SYOC_C & Symphoricarpos occidentalis (Cover) & Western snowberry \\
\hline
\end{tabular}




$\begin{array}{lll}\text { SYOC_H } & \text { Symphoricarpos occidentalis } \text { (Height) } & \text { Western snowberry } \\ \text { TORA_C } & \text { Toxicodendron radicans (Cover) } & \text { Eastern poison ivy } \\ \text { TORA_H } & \text { Toxicodendron radicans (Height) } & \text { Eastern poison ivy } \\ \text { ULAM_C } & \text { Ulmus americana (Cover) } & \text { American elm } \\ \text { ULAM_H } & \text { Ulmus americana }(\text { Height) } & \text { American elm }\end{array}$


Table A1.5. A list of herbaceous species that were unique to each transition class, along with the number of sampling site and number of quadrats that each species was recorded in.

\begin{tabular}{|c|c|c|c|}
\hline Abbrev. & Species & Number of Sites & Number of Quadrats \\
\hline \multicolumn{4}{|c|}{ Unburned Forest } \\
\hline & Berberis Repens & 1 & 1 \\
\hline & Carex saximontana & 1 & 2 \\
\hline & Cynoglossum officinale & 1 & 2 \\
\hline & Cystopteris fragilis & 5 & 22 \\
\hline & Descurainia pinnata & 1 & 1 \\
\hline & Elymus canadensis & 1 & 10 \\
\hline & Galium triflorum & 1 & 3 \\
\hline & Viola nuttallii & 1 & 1 \\
\hline & Hieracium umbellatum & 1 & 1 \\
\hline & Senecio plattensis & 1 & 1 \\
\hline \multicolumn{4}{|c|}{ Forest $\rightarrow$ Forest } \\
\hline & Cirsium arvense & 1 & 3 \\
\hline & Galium aparine & 1 & 1 \\
\hline & Galium boreale & 1 & 2 \\
\hline & Phlox andicola & 1 & 3 \\
\hline & Solidago mollis & 1 & 2 \\
\hline & Anaphalis margaritacea & 1 & 2 \\
\hline & Glycyrrhiza lepidota & 1 & 2 \\
\hline & Vitus riparia & 1 & 1 \\
\hline \multicolumn{4}{|c|}{ Forest $\rightarrow$ Grassland } \\
\hline & Anemone cylindrica & 1 & 1 \\
\hline & Camelina microcarpa & 1 & 2 \\
\hline
\end{tabular}


Euphorbia missurica

Melilotus officinalis

Sisyrinchium montanum

Verbena stricta

Bouteloua hirsuta

Brickellia eupatorioides

Draba reptans

Lesquerella arenosa

Oxytropis lambertii

1

Solidago canadensis

1

4

Aster oblongifolia

Eriogonum cernuum

1

1

Calochortus nuttallii

1

2

Euphorbia robusta

1

1

Machaeranthera tanacetifolia

1

3

Sporobolus compositus

1

1

Unburned Grassland

Linum Rigidum

1

1

Opuntia humifusa

3

4

Penstemon albidus

1

1

Physalis longifolia

3

17

Cirsium plattensis

1

1

Panicum capillare

1

2

Artemisia filifolia

2

6

Grassland $\rightarrow$ Grassland

Aristida purpurea

2

8

Artemisia dracunculoides 
Hedeoma hispida

Arabis hirsuta

Eremogone hookeri

Erysimum cheiranthoides

Penstemon angustifolia

Physalis hispida
1

1

1

1

1

1
9

4

1

1

2

1 
Table A1.6. A list of understory woody plant and bird species unique to each transition class, along with the number of sampling sites each species was recorded in.

\begin{tabular}{|c|c|c|}
\hline Abbrv. & Species & Number of Sites \\
\hline \multicolumn{3}{|c|}{ Unburned Forest } \\
\hline BHGR & Pheucticus melanocephalus & 1 \\
\hline CEWA & Bombycilla cedrorum & 3 \\
\hline AMKE & Falco sparverius & 1 \\
\hline OVEN & Seiurus aurocapillus & 1 \\
\hline PLVI & Vireo plumbeus & 3 \\
\hline PYNU & Sitta pygmaea & 1 \\
\hline RBNU & Sitta canadensis & 1 \\
\hline ACNE & Acer negundo & 1 \\
\hline MARE & Mahonia repens & 4 \\
\hline PRAM & Prunus americana & 5 \\
\hline RIAU & Ribes aureum & 1 \\
\hline RIOX & Ribes oxyacanthoides & 1 \\
\hline \multicolumn{3}{|c|}{ Forest $\rightarrow$ Forest } \\
\hline AMRO & Turdus migratorius & 1 \\
\hline BUOR & Icterus bullockii & 1 \\
\hline CONI & Chordeiles minor & 1 \\
\hline ULAM & Ulmus americana & 1 \\
\hline \multicolumn{3}{|c|}{ Forest $\rightarrow$ Grassland } \\
\hline BRTH & Toxostoma rufum & 1 \\
\hline \multicolumn{3}{|c|}{ Grassland } \\
\hline GRSP & Ammodramus savannarum & 5 \\
\hline ARFI & Artemisia filifolia & 5 \\
\hline
\end{tabular}


Grassland $\rightarrow$ Grassland

PRFA Falco mexicanus 1

